archives-ouvertes

\title{
Water management practices exacerbate nitrogen retention in Mediterranean catchments
}

Estela Romero, Josette Garnier, Gilles Billen, Franz Peters, Luis Lassaletta

\section{To cite this version:}

Estela Romero, Josette Garnier, Gilles Billen, Franz Peters, Luis Lassaletta. Water management practices exacerbate nitrogen retention in Mediterranean catchments. Science of the Total Environment, Elsevier, 2016, 573, pp.420-432. 10.1016/j.scitotenv.2016.08.007 . hal-01366666

\section{HAL Id: hal-01366666 https://hal.sorbonne-universite.fr/hal-01366666}

Submitted on 15 Sep 2016

HAL is a multi-disciplinary open access archive for the deposit and dissemination of scientific research documents, whether they are published or not. The documents may come from teaching and research institutions in France or abroad, or from public or private research centers.
L'archive ouverte pluridisciplinaire HAL, est destinée au dépôt et à la diffusion de documents scientifiques de niveau recherche, publiés ou non, émanant des établissements d'enseignement et de recherche français ou étrangers, des laboratoires publics ou privés. 


\title{
Water management practices exacerbate nitrogen retention in Mediterranean catchments
}

Estela Romero ${ }^{1,2, *}$, Josette Garnier1,3, Gilles Billen ${ }^{1,3}$, Franz Peters ${ }^{2}$ and Luis Lassaletta ${ }^{1,4}$

1. Université Pierre et Marie Curie (UPMC), UMR 7619 Metis, Paris, 75005, France

2. Institut de Ciències del Mar (CSIC), Barcelona, o8003, Spain

3. Centre National de la Recherche Scientifique (CNRS), UMR 7619 Metis, Paris, 75005, France

4. PBL, Netherlands Environmental Assessment Agency, 3721 MA, Bilthoven, The Netherlands

* To whom correspondence should be addressed: estela.romero@upmc.fr

\begin{abstract}
Nitrogen $(\mathrm{N})$ retention sensu lato refers to all processes preventing new reactive nitrogen brought into watersheds through agricultural or industrial activities to be exported by river systems to the sea. Although such processes protect marine systems from the threat of eutrophication and anoxia, they raise other environmental issues, including the acidification of soils, the emission of ammonia and greenhouse gases, and the pollution of aquifers. Despite these implications, the factors involved in $\mathrm{N}$ retention are still poorly controlled, particularly in arid and semi-arid systems. The present study evaluates the $\mathrm{N}$ fluxes of 38 catchments in the Iberian Peninsula with contrasting climatic characteristics (temperate and Mediterranean), land uses, and water management practices. This diversity allows addressing the contribution of physical and socioecological factors in $\mathrm{N}$ retention, and more specifically, exploring the relation between $\mathrm{N}$ retention and water regulation. We hypothesise that the extreme flow regulation implemented in the Mediterranean enhances the high $\mathrm{N}$ retention values associated with arid and semi-arid regions. The results show that reservoirs and irrigation channels account for $>50 \%$ of the variability in $\mathrm{N}$ retention values, and above a certain regulation threshold, $\mathrm{N}$ retention peaks to values $>85-90 \%$. Future climate projections forecast a decrease in rainfall and an increase in agricultural intensification and irrigation practices in many world regions, most notably in arid and semi-arid areas. Increased water demand will likely lead to greater flow regulation, and the situation in many areas may resemble that of Iberian Mediterranean catchments. High $\mathrm{N}$ retention and the associated environmental risks must therefore be considered and adequately addressed.
\end{abstract}

KEYWORDS: N retention; water regulation; reservoirs; irrigation; Mediterranean climate; river basin

\section{INTRODUCTION}

Nitrogen (N) is a key element for plant growth, and as such it plays a central role in the world's agricultural production and in the capacity of the planet to feed human populations 
(Sutton et al., 2011). Such a pivotal role sparked intense research on its sources and potential supply, and led to the discovery of the Haber-Bosch process in the early years of the 2oth century. The Haber-Bosch process has allowed a great increase in crop yields worldwide (Smil, 2001; Erisman et al., 2008; Gruber \& Galloway, 2008), but it has remarkably altered the $\mathrm{N}$ budget in most of the terrestrial and aquatic compartments involved, at one stage or another, in the N cycle (Galloway et al., 2003; Rockström et al., 2009).

Globally, the input of biologically available $\mathrm{N}$ to terrestrial ecosystems has more than doubled in the past century (Gruber \& Galloway, 2008). The ecological significance of such an enormous increase is far-reaching and has been thoroughly reviewed in a number of studies (the European Nitrogen Assessment provides a comprehensive summary; Sutton et al., 2011). We here focus on one aspect of the complex biogeochemical cycle involved, i.e. the proportion of reactive $\mathrm{N}$ brought into watersheds through anthropogenic activities that is eliminated to the atmosphere or retained on land during its cascading travel through the soil, aquifers and river network before reaching the sea. Specifically, we account for the percentage of $\mathrm{N}$ that remains in the terrestrial and freshwater systems (herein considered ' $\mathrm{N}$ retention' sensu lato, as in Howarth et al., 1996), and the fraction that is conveyed to the marine compartment.

The proportion of $\mathrm{N}$ that is exported to the sea or accumulated/eliminated on land involves different environmental issues. Large amounts of $\mathrm{N}$ on terrestrial compartments are related to shifts in community structure and function, the acidification of soils and freshwater lakes, the emission of ammonia and greenhouse gases, and high nitrate concentrations in streams and aquifers (e.g. Henriksen \& Brakke, 1988; Schulze, 1989; Crabtree \& Bazzaz, 1993; Spalding \& Exner, 1993; Bowman et al., 1995; Camargo \& Alonso, 2006; Grizzetti et al., 2011). On the other hand, high exports of $\mathrm{N}$ to coastal waters can induce coastal eutrophication, harmful algal blooms and eventually episodes of anoxia (e.g. Nixon, 1995; Cloern, 2001; Beman et al., 2005; Howarth et al., 2011; Romero et al., 2013).

Despite these implications, the functioning of retention processes is still poorly controlled, particularly in arid and semi-arid regions. Retention may be related to climatic and hydrological features (Behrendt \& Opitz, 2000; Howarth et al., 2006; Lepistö et al., 2006; Schaefer \& Alber, 2007) or to socioecological factors such as land and water use (Caraco \& Cole, 2001; Pacheco et al., 2015; Pacheco \& Sanches Fernandes, 2016), and a number of general principles have been proposed at the global scale regarding the role of specific discharge and mean temperature (Billen et al., 2010). Yet, at smaller scales, the contribution of each factor remains largely uncharacterised.

River catchments in the Iberian Peninsula are particularly suitable to test the importance of physical and socio-ecological factors in the retention of N. First, Iberian catchments can be divided into two different groups with distinct climatological features: rivers in the north and the north-western façade present temperate climates, while in the east and mid-southern regions rivers present typical Mediterranean conditions. These contrasting physical characteristics are matched by different land uses and notably by different water management practices (Álvarez-Cabria et al., 2016), and thus allow an assessment of the various factors 
involved in retention and export processes. Second, partly as a result of the delayed implementation of monitoring networks, rivers in Southern Europe have been traditionally less studied than those in Northern European countries. This paucity of data is particularly pronounced in the Mediterranean regions, where stream flows are low and irregular, and they are very frequently omitted in large-scale studies. Third, arid and semi-arid regions represent a large fraction of the Earth's land, and they are predicted to increase as a consequence of global warming (IPCC, 2014). In many of these regions, as has occurred in semi-arid catchments of the Iberian Peninsula during the past few decades, intensification of agriculture and expansion of irrigation facilities are foreseen (water withdrawals for irrigation are projected to increase by 11\% from 2005 to 2050; Bruinsma, 2009). Under these circumstances, better knowledge of what physical and human-related factors operate on the retention of $\mathrm{N}$ in Iberian watersheds may be very helpful to understand future $\mathrm{N}$ trends in many other world regions.

In a previous study, Lassaletta et al. (2012) discussed the relevance of land management and flow regulation for the fate of $\mathrm{N}$ within the Ebro River catchment (NE Spain). The study presented an overall $\mathrm{N}$ budget in the basin and detailed $\mathrm{N}$ calculations in different subcatchments, and hypothesised that agricultural and water management practices had a major influence on $\mathrm{N}$ retention. The Ebro River is a case of extreme human intervention, with over $95 \%$ of the watershed area under some type of regulation (Liquete et al., 2005; Lorenzo-Lacruz et al., 2012). Far from being unusual, however, this situation is found in many other streams around the world. In the same vein, Törnqvist et al. (2015) addressed the influence of irrigated agriculture to the cycling and transport of $\mathrm{N}$ in the semi-arid Amu Daria River basin in Central Asia. These authors found that the water diversions, recirculation, and changes in flow-paths related to irrigation facilities deeply modified the river export of $\mathrm{N}$. The role of reservoirs and ponds, another example of human intervention in river networks, was also found to be substantial in river nutrient delivery by Powers et al. (2015), particularly when reservoirs were located in agricultural landscapes.

This study aims to explore whether the relation observed between $\mathrm{N}$ retention and water flow regulation, and specifically the patterns described for the Ebro River by Lassaletta et al. (2012), hold for other rivers with similar features, and if the opposite is true in rivers with substantially different characteristics. To ease comparisons with Lassaletta et al. (2012), we assessed the fluxes of $\mathrm{N}$ by means of the Net Anthropogenic Nitrogen Input (NANI) approach (Howarth et al., 1996). The NANI accounts for four main reactive $\mathrm{N}$ input types, namely fertilisers, biological fixation, atmospheric deposition and the net import of food and feed. This can be easily calculated and underlines the importance of human activities, which is particularly convenient for our objectives.

The study reviews the $\mathrm{N}$ fluxes in 38 catchments of the Iberian Peninsula, accounting for all $\mathrm{N}$ inputs and outputs, and finally working out the export to the sea and the retention of $\mathrm{N}$ within the basins. We discuss differences in the retention of $\mathrm{N}$ in light of different hydrological features, agricultural practices, and water management strategies, and we discuss the 
singularities of Mediterranean (or broadly, semi-arid) versus temperate rivers and the need to consider these singularities when designing and planning effective $\mathrm{N}$ management measures.

\section{MATERIALS AND METHODS}

\subsection{Land fluxes}

We have selected 38 river basins situated in areas in a Mediterranean or temperate climate including enough information to estimate nutrient fluxes at the river mouth (2000-2010 period). To describe the $\mathrm{N}$ fluxes entering the territory, we used the NANI approach. The method has been successfully applied in a number of studies (Howarth et al., 1996; Billen et al., 2009a; Hong et al., 2013; Goyette et al., 2016), notably in the European Nitrogen Assessment (Sutton et al., 2011). The approach considers all the anthropogenic "new" N input fluxes associated with: (1) synthetic fertiliser application, (2) biological $\mathrm{N}$ fixation, (3) net atmospheric deposition and (4) net import of food and feed. The output flux comprises (5) the export of $\mathrm{N}$ at the outlet of the river.

Once all input and output fluxes have been computed, a retention value can be derived as the difference between total inputs and riverine outputs at the coastal zone. We are well aware that used in this way, the word "retention" does not refer to retention processes strictly but also encompasses a fraction of $\mathrm{N}$ that may be removed by subsequent denitrification processes within the soil or freshwater compartments, and another fraction stored in the landscape as vegetal biomass or soil or organic matter sediment (Lepistö et al., 2001; Lassaletta et al., 2012). Nevertheless, this retention sensu lato gives a good idea of the proportion of new $\mathrm{N}$ inputs that does not reach the sea, which is the aspect we seek to consider herein.

Data sources for each of the required NANI terms are given below (a summary is included in the supplementary material, Table $\mathrm{S} 1$ ). To estimate the $\mathrm{N}$ inputs into the catchments, data were averaged for the 2000-2010 period (whenever possible).

(1) Data on synthetic fertilisers were retrieved from the CAPRI model by using the spatialised layer for Spain and Portugal for the year 2002 (Leip et al., 2011; and A. Leip, personal communication). To obtain a figure closer to the decadal average, the 2002 data were corrected with the values of total fertilisation in each country between 2000 and 2010.

(2) Biological $\mathrm{N}$ fixation (BNF) was determined for $\mathrm{N}$-fixing crops and grasslands with data from the EUROSTAT database, including dry, green, and leguminous fodder; soybeans, and managed and natural grasslands. BNF was calculated following the formula proposed by Anglade et al. (2015), which takes into account the yield, the harvested index, the percentage of $\mathrm{N}$ fixed and the above-/belowground ratio by plant type (see the supplementary material in Lassaletta et al., 2014a, for detailed information on the parameters). For managed and natural grassland, the same formula was applied but considering $30 \%$ leguminous plants in the total production. 
In the case of rice, which is not a $\mathrm{N}$-fixing crop but is grown under flooded conditions where $\mathrm{N}$ fixation by cyanobacteria occurs, a fixed rate of $33 \mathrm{~kg} \mathrm{~N} \mathrm{ha}^{-1} \mathrm{yr}^{-1}$ was applied (Herridge et al., 2008).

(3) Spatialised information on atmospheric fluxes, either inputs by deposition or outputs by emission of gaseous forms were obtained from the EMEP $50 \times 50-\mathrm{km}$ grid (http://www.emep.int). A slight modification of the original NANI procedure (Howarth et al., 1996) was performed, as described in Lassaletta et al. (2012). While Howarth et al. (1996, 2006, 2012) exclude reduced forms from $\mathrm{N}$ deposition calculations - on the assumption that reduced $\mathrm{N}$ is mostly related to local re-deposition of volatilised ammonia from fertiliser and animal waste products - we consider the net deposition (deposition minus emission) of both oxidised and reduced forms. Calculated as such, it is possible to determine whether reduced $\mathrm{N}$ forms are entering the catchment from abroad or, conversely, if the catchment is exporting $\mathrm{N}$ to neighbouring areas.

(4) Net import of food and feed was calculated as the difference between the consumption of human food and animal feed in each catchment and crop/grassland production (Billen et al., 2010).

Crop and grassland production was first estimated by processing the information provided by EUROSTAT at the NUTS3 level (Nomenclature of Territorial Units for Statistics, European division), and then these regional calculations were spatialised using the layer of CORINE Land Cover project (CLC) for the year 2006 (http://www.eea.europa.eu/publications/CORolandcover). The EUROSTAT agricultural database includes information on productivity and surface areas for different crops and grasslands (cereals, pulses, tubers, industrial crops, fodder and permanent crops, managed and natural grasslands). We averaged all the available information for the decade studied. Crop $\mathrm{N}$ output calculations were based on the $\mathrm{N}$ yield and surface area of each crop at each NUTS3 unit, and on the N content of the harvested products (Lassaletta et al., 2014b). To spatialise the regional information, we prepared a map grouping the output results and the CORINE uses into four categories: crops, managed grasslands, natural grasslands and a mixed category (which includes urban land and open spaces with little or no vegetation, but also patchy agricultural areas melded with forests and shrubs). The proportion of crops and grasslands in the mixed category was ascribed following the factors applied in Lassaletta et al. (2012). The direct downscaling NUTS3-CLC can generate several distortions due to (1) the nonexistence of fallow land in the NUTS3 calculation, (2) the erroneous classification of proportions of each use in the mixed category and (3) errors in the CLC satellite classification. These potential biases were corrected considering particular surfaces of fallow land in the cropland or different proportions of the mixed category until obtaining the same actual productive surface in both, i.e. in the NUTS 3 approach and in the aggregation of the CLC data from each NUTS3 area. The regional results on BNF were also downscaled following the same procedure. 
Statistics on livestock heads were obtained from the Spanish Ministry of Agriculture at the municipal scale (detailed 2009 survey) and at the NUTS3 level (EUROSTAT) for the Portuguese part. Feed consumption by cattle was assumed to be equal to animal excretion, and we applied the national excretion factors provided by the UN national inventories (http://newsroom.unfccc.int). The human consumption of food products was calculated using the information on protein supply provided in the national food balance sheets of the FAOSTAT database for 2005 (http://faostat3.fao.org/), combined with spatialised data on population distribution from Eurostat.

The overall balance between production and demand determines the autotrophic or heterotrophic status of territories (all in terms of N, Quynh et al., 2005; Billen et al. 2009b). Broadly, those regions specialised in crop farming and exporting their production have an autotrophic status, while the areas where the consumption of food and feed by humans and livestock exceeds agricultural production have a heterotrophic character. The autotrophic or heterotrophic characteristic is indeed not trivial: while in autotrophic catchments the main source of $\mathrm{N}$ is the use of inorganic fertilisers, in heterotrophic catchments most $\mathrm{N}$ inputs are in the form of organic $\mathrm{N}$ compounds (Billen et al., 2011). This divergence influences the processes on land and consequently the percentage of $\mathrm{N}$ retention.

(5) The riverine export of $\mathrm{N}$ to coastal waters was calculated using data on river flow and water quality provided by several water authorities from Spain and Portugal (Table 1). Further details on the calculation of the river fluxes are provided in the next section.

\subsection{River fluxes}

We gathered information on river flow and water quality for 38 Iberian rivers (Fig. 1). To have the best possible estimate of river export we selected those monitoring stations that were closest to the river mouth and where the time series were at least a few years long. In most cases, both flow and nutrient concentrations were measured in the same location; if that was not possible, however, we used information from the nearest station available.

We collected data for the longest period available, in some cases from the 1980 os to the present, although to close the NANI budget and be consistent with the land fluxes, we only used data from the 2000-2010 period to compute the export flux. Only in a few rivers where either the flow or the $\mathrm{N}$ concentration data were not available for the 2000-2010 period, was the complete time series used to calculate an average year (i.e. a year in which each month corresponds to the average value of that month for the whole data set) of flow and $\mathrm{N}$ concentrations, and these were multiplied to obtain the average annual export.

Water quality data sets comprised monthly measurements of inorganic $\mathrm{N}$ (nitrate, nitrite, ammonium, N Kjeldahl) and total nitrogen (TN). When the latter was not provided, we

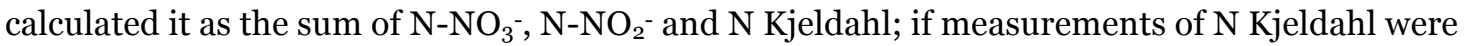
not available either, we used the formula in Garnier et al. (2010), where $\mathrm{TN}=1.2 \times\left(\mathrm{N}^{-\mathrm{NO}_{3}}{ }^{-}\right)+$ o.1. This formula has been shown to slightly underestimate TN values in catchments with little 
agricultural land or where $\mathrm{N}$ inputs are mostly related to urban sewage (Romero et al., 2013). This is the case of the Besòs and the Llobregat rivers in NW Spain, which show a major percentage of urban land and very high population density. Consequently, for these two rivers, the TN export fluxes given here may be slightly lower than the actual values.

Annual $\mathrm{N}$ fluxes were obtained using flow-adjusted concentrations, applying the formula:

$$
\mathrm{N} \text { flux }=\mathrm{Q}_{\mathrm{m}} \times\left(\mathrm{K} \times \sum\left(\mathrm{C}_{\mathrm{i}} \times \mathrm{Q}_{\mathrm{i}}\right) / \sum \mathrm{Q}_{\mathrm{i}}\right)
$$

where $\mathrm{K}$ is the conversion factor to take the recorded period into account (e.g., 365 days), $\mathrm{C}_{\mathrm{i}}$ the instantaneous concentration, $Q_{i}$ the corresponding instantaneous water flow, and $Q_{m}$ the mean water flow for the period considered (Verhoff et al., 1980; Walling and Webb, 1985). Flowadjusted concentrations are commonly used when assessing annual fluxes and are recommended in monitoring guidelines such as those of national environmental agencies (e.g. the Spanish Ministry of Agriculture, Food and the Environment) or international conventions (Convention for the protection of the marine environment of the North-East Atlantic, OSPAR 1998).

Finally, to allow comparisons between catchments, nutrient fluxes were re-scaled per square kilometer, dividing the flux by the area of the corresponding river basin.

\subsection{Number of reservoirs and water regulation indices}

Data on the number of dams and reservoirs per catchment and their maximum (potential) and mean (live) water storage capacity are included in Table 2 . We used the maximum and the actual average capacity to calculate the Impounded Runoff (IR) Index developed by Batalla et al. (2004). These authors propose the IR as a useful proxy to assess the hydrologic alteration caused by water management practices, one of the multiple facets of the progressive anthropisation of rivers. The IR index is computed as the live storage capacity ( $\mathrm{IR}_{\text {stocks }}$ ) or the total capacity (IR), whenever live values are not available, divided by the river's mean annual runoff.

Additionally, we calculated an Indirect Alteration (IA) Index, as presented by Belmar et al. (2013). The IA is a function of the percentage of irrigated land, the number of dams and the cubic hectometres of regulatory capacity. Briefly, basins are assigned between $\mathrm{o}$ and 8 points for each variable according to their percentile value within the data range (excluding zero values). The 1st, 20th, 40th, 6oth, 80th, 90th, 95th and 98th percentiles are used as thresholds for assigning the corresponding punctuation. The points for all three variables are then added to obtain the IA, which ranges from o (minimum flow alteration) to 24 (maximum flow alteration). The authors note that this is an indirect index, derived from variables associated with the main hydrologic pressures in the basin, and it does not take into account direct management features, e.g. specific regulation of dams, or inter-basin water transfers that supply cities and industrial estates. Nevertheless, it offers synthetic, valuable information on the degree of intervention in the watershed. 


\subsection{Climatic features: Mediterranean versus temperate catchments}

The climatic characteristics play an essential role in the regularity and the magnitude of river discharge (i.e., the flow regime) and influence land uses and water management practices within the basins both directly and indirectly. They are therefore crucial for nutrient cycling (Aguilera et al., 2015). The Iberian Peninsula shows a strong temperature and rainfall gradient that decreases from NW to SE and fits roughly with a natural geographic classification of the catchments. The Galician and the Cantabrian façade (N-NW) correspond to temperate (TEMP) regions: rainy, with moderately cold winters and warm summers. The rest can be ascribed to Mediterranean (MED) climate areas: the western and central parts show moderate rainfall and a wider annual temperature range, with cold winters and hot summers; the S, E and SE present low and irregular rainfall, hot summers and mild winters. Despite these differences, all Mediterranean basins are characterised by a pronounced dry season. Figure 2 shows the typical temperature and precipitation regimes of the MED and TEMP groups and their average surface runoff. Meteorological data (1980-2010) were obtained from the CEDEX (Spain) and the SNIRH (Portugal), and consisted of monthly means of temperature, rainfall and surface runoff per river basin.

\section{RESULTS}

\subsection{Land uses and associated $\mathbf{N}$ fluxes}

$\mathrm{N}$ fluxes presented here for each of the factors considered in the NANI are average values for the 2000-2010 period (Table 3, Figure 3). An interval of 10 years can smooth the effects of very dry or very wet years and provide an accurate idea of the typical annual flows.

Figure 3a shows land use in the basins studied. Broadly, grasslands are concentrated in the northern temperate basins, while Mediterranean catchments have a greater proportion of crops, and mixed agricultural and forested areas. The latter, along with natural pastures, are particularly abundant in the west.

The NANI describes anthropogenic $\mathrm{N}$ inputs in the basins and is the sum of the four components explained in the Methods section: NANI $=\mathrm{N}$ fertilisers + biological $\mathrm{N}$ fixation + atmospheric $\mathrm{N}$ deposition + net $\mathrm{N}$ import. On average, the NANI for the whole peninsula is 3121 $\mathrm{kg} \mathrm{N} \mathrm{km}^{-2} \mathrm{y}^{-1}$, although there are large variations between catchments (ranging from 2149 to 11,634, Fig. 3i). Billen et al. (2011) calculated the NANI for a set of European watersheds. The NANI values in the Iberian Peninsula are very similar to those of other basins in the Mediterranean region (southern France, Italy, Greece), but significantly lower than those of central Europe (in Belgium, the Netherlands, Denmark and Germany, river basins have NANI values of $5000 \mathrm{~kg} \mathrm{~N} \mathrm{~m}^{-2} \mathrm{y}^{-1}$, and in some cases even exceed 20,000 $\left.\mathrm{kg} \mathrm{N} \mathrm{m}^{-2} \mathrm{y}^{-1}\right)$.

The spatialised input fluxes of the NANI are depicted in Figure $3 \mathrm{~b}-\mathrm{h}$. Average values per group (MED/TEMP) are included in Table 3, and the detailed values per catchment can be 
found in the Supplementary Material. Fluxes are always expressed in $\mathrm{kg}$ of $\mathrm{N}$ per year per unit area, so that the basins can be directly compared.

The fertilisation of agricultural land represents one of the largest $\mathrm{N}$ fluxes in many Iberian basins, notably in Mediterranean catchments with intensive agriculture. The input of synthetic fertilisers averages $2360 \mathrm{~kg} \mathrm{~N} \mathrm{~km}^{-2} \mathrm{y}^{-1}$ for all rivers considered, which corresponds to an annual mean fertiliser application rate of $59 \mathrm{~kg} \mathrm{~N}$ per ha of agricultural surface. Inputs are particularly high in the Guadiana, the Guadalquivir, the Sado and the Douro basins (approx. 2600-3000 kg $\mathrm{N} \mathrm{km}^{-2} \mathrm{y}^{-1}$, and an application rate of 51-64 $\mathrm{kg} \mathrm{N} \mathrm{ha}^{-1} \mathrm{y}^{-1}$ ). Although temperate catchments tend to have lower fertiliser inputs, high application rates are reached in the Bidasoa, Urumea, Herrerias and Sella, all with values $>80 \mathrm{~kg} \mathrm{~N} \mathrm{ha}^{-1} \mathrm{y}^{-1}$.

Biological N fixation (BNF) accounts for about $12 \%$ of the NANI in the peninsula, and displays clear differences between the two climatic regions. BNF varies around $800 \mathrm{~kg} \mathrm{~N} \mathrm{~km}^{-2} \mathrm{y}^{-1}$ in most temperate basins (22\% of the total anthropogenic inputs), while it hardly reaches 400 $\mathrm{kg} \mathrm{N} \mathrm{km}^{-2} \mathrm{y}^{-1}$ in Mediterranean catchments (11\% of the NANI), with even lower values in several rivers ( $<200 \mathrm{~kg} \mathrm{~N} \mathrm{~km}^{-2} \mathrm{y}^{-1}$ in the Jucar, Segura, Guadalquivir and Mondego). The differences are even greater when BNF inputs are calculated per ha of agricultural surface. BNF averages $8 \mathrm{~kg} \mathrm{~N}$ ha-1 $^{-1} \mathrm{y}^{-1}$ in the MED, while it is $36 \mathrm{~kg} \mathrm{~N} \mathrm{ha}^{-1} \mathrm{y}^{-1}$ in TEMP catchments.

Atmospheric net deposition of $\mathrm{N}$ (Table S2) is also heterogeneous across the territory. On average, the highest entries are observed in temperate catchments $\left(215 \mathrm{~kg} \mathrm{~N} \mathrm{~km}^{-2} \mathrm{y}^{-1}\right)$, three times higher than the average inputs of Mediterranean basins $\left(65 \mathrm{~kg} \mathrm{~N} \mathrm{~km}^{-2} \mathrm{y}^{-1}\right)$. Net deposition values in MED catchments, however, are rather variable: $\mathrm{N}$ deposition is high in the northernmost MED rivers (Ter, Tordera, Besòs), with values well above $300 \mathrm{~kg} \mathrm{~N} \mathrm{~km}^{-2} \mathrm{y}^{-1}$, but it is low or even negative in the south (meaning that $\mathrm{N}$ is exported from the catchment via atmospheric transport).

Looking separately at oxidised and reduced compounds (Fig. $3 \mathrm{~d}-\mathrm{e}$ ), it is clear that high deposition of nitrogen oxides $\left(\mathrm{NO}_{\mathrm{x}}\right)$ occurs mainly in the $\mathrm{NE}$ half of the Iberian Peninsula, affecting some Mediterranean basins (approx. $800 \mathrm{~kg} \mathrm{~N} \mathrm{~km}^{-2} \mathrm{y}^{-1}$ in the Ter, Tordera and Besòs) and the temperate catchments of the Cantabrian façade $\left(\sim 400 \mathrm{~kg} \mathrm{~N} \mathrm{~km}^{-2} \mathrm{y}^{-1}\right)$. In terms of $\mathrm{N} \mathrm{NO}_{\mathrm{x}}$ inputs are partly offset by losses due to ammonia volatilisation over most of the area (note that $\mathrm{NH}_{3}$ deposition values are negative in most Iberian catchments). $\mathrm{NH}_{3}$ volatilisation is particularly high in Mediterranean areas, which explains why MED basins have overall lower net $\mathrm{N}$ deposition values.

The net import of $\mathrm{N}$ is the difference between crop production and the consumption of food and feed by humans and cattle. When $\mathrm{N}$ production exceeds consumption, the basin is considered autotrophic, whereas if demand surpasses production we tag the basin as heterotrophic. Crop production represents around $1600 \mathrm{~kg} \mathrm{~N} \mathrm{~km}^{-2} \mathrm{y}^{-1}$ in the Iberian Peninsula, with similar average values in the MED and TEMP groups (Table 3). The actual production values per hectare of agricultural surface, however, are less homogeneous across basins: crop 
production in TEMP catchments is nearly twofold that of MED catchments (70 versus $38 \mathrm{~kg} \mathrm{~N}$ ha $\left.^{-1} \mathrm{y}^{-1}\right)$.

Food and feed consumption also show a quite uneven geographical distribution. Human consumption of food peaks in those basins where the population density is very high, particularly near the coast (Fig. 3g). In the Besòs, for instance, food demand is about $8000 \mathrm{~kg} \mathrm{~N}$ $\mathrm{km}^{-2} \mathrm{y}^{-1}$, and values are ca. $1200 \mathrm{~kg} \mathrm{~N} \mathrm{~km}^{-2} \mathrm{y}^{-1}$ in the neighbouring Llobregat basin. The consumption of food is also high (over $1000 \mathrm{~kg} \mathrm{~N} \mathrm{~km}^{-2} \mathrm{y}^{-1}$ ) in a number of temperate populated basins (e.g., Nervion, Deba, Oyarzun). Moreover, the demand for $\mathrm{N}$ in feed for livestock is maximum in most of these areas: many temperate rivers have values between 3000 and 5000 $\mathrm{kg} \mathrm{N} \mathrm{km}^{-2} \mathrm{y}^{-1}$ (animal demand of $\mathrm{N}$ in TEMP basins averages $2580 \mathrm{~kg} \mathrm{~N} \mathrm{~km}^{-2} \mathrm{y}^{-1}$ ) and $5800 \mathrm{~kg} \mathrm{~N}$ $\mathrm{km}^{-2} \mathrm{y}^{-1}$ are reached in the Ter basin. As a result, all TEMP basins and the northernmost MED basins present very high net $\mathrm{N}$ import values and are markedly heterotrophic, i.e. production is not sufficient to meet the high demand for food and feed. In the rest of the area, crop production and food and feed demand are more balanced. The Tagus and the Mondego basins are heterotrophic, but net $\mathrm{N}$ imports are approximately $1000-1200 \mathrm{~kg} \mathrm{~N} \mathrm{~km}^{-2} \mathrm{y}^{-1}$ (far from the 9807 of the Besòs basin), and there are several autotrophic catchments (e.g. Guadalquivir, Guadiana, Sado, Duero).

On the whole, the Iberian Peninsula is net heterotrophic and requires the import of $317 \mathrm{~kg} \mathrm{~N}$ $\mathrm{km}^{-2} \mathrm{y}^{-1}$ (the feed consumption is fivefold the food consumption, Table 3).

\subsection{River export to coastal seas}

The export of $\mathrm{N}$ to coastal seas is presented in Figure 4. All in all, Iberian rivers export $127 \mathrm{Gg}$ $\mathrm{N}^{-1}$ to the adjacent coastal seas. Two-thirds of this $\mathrm{N}$ flux is conveyed to the Atlantic Ocean, where the largest Iberian rivers discharge. Spatialising the export per square kilometre of catchment, however, it is clear that the highest $\mathrm{N}$ loads occur in the northern half of the peninsula, where anthropogenic inputs are also larger. On average, export fluxes in temperate catchments (941 $\mathrm{kg} \mathrm{N} \mathrm{km}^{-2} \mathrm{y}^{-1}$ ) are fourfold the export of Mediterranean rivers (242 $\mathrm{kg} \mathrm{N} \mathrm{m}^{-2} \mathrm{y}^{-}$ 1), although NANI values are only $17 \%$ higher. Further, there are some remarkably low outputs in the Jucar, Segura, Guadiana and Sado (1-115 $\mathrm{kg} \mathrm{N} \mathrm{m}^{-2} \mathrm{y}^{-1}$ ), which are all Mediterranean watersheds with extensive arid regions and very low annual rainfall and runoff values (300-60o $\mathrm{mm} \mathrm{y}^{-1}$ of rainfall, $<100 \mathrm{~mm} \mathrm{y}^{-1}$ of runoff).

According to the figures in Billen et al. (2011), Iberian rivers are on the low range of European catchments, which show $\mathrm{N}$ delivery rates on the order of $200-4000 \mathrm{~kg} \mathrm{~N} \mathrm{~km}^{-2} \mathrm{y}^{-1}$. In our case, most rivers have values $<500 \mathrm{~kg} \mathrm{~N} \mathrm{~km}^{-2} \mathrm{y}^{-1}$, and the maximum export was found to be $2149 \mathrm{~kg} \mathrm{~N} \mathrm{~km}^{-2} \mathrm{y}^{-1}$ (the Miera River, in the northern façade).

We examined whether the contrasted relationship between $\mathrm{N}$ inputs and river export observed by Schaefer \& Alber (2007) and Sobota et al. (2009) for US catchments with different climatological characteristics occurred as well in the Iberian Peninsula between temperate and Mediterranean catchments. MED and TEMP basins fell clearly into two separate groups (Fig. 5). 
The Mondego basin, which is a medium-sized catchment with annual precipitation values higher than the MED average (1008 vs. $600 \mathrm{~mm} \mathrm{y}^{-1}$ ), pooled with the northern catchments, and was therefore included in the TEMP group to calculate the relationships. Both groups of rivers presented a positive relation between anthropogenic $\mathrm{N}$ inputs and river export fluxes, but in accord with the observations by Schaefer \& Alber (2007) and Sobota et al. (2009), the slope was much higher for TEMP basins than for MED basins. There was also a good match in the equations with regard to previous studies, notably for the TEMP group. The present results are consistent, for instance, with the correlation calculated by Billen et al. (2011) for a large set of European catchments, although the background $\mathrm{N}$ export (i.e. the independent term in the equation) is somewhat lower for Iberian rivers.

\subsection{Retention processes}

Riverine export to coastal seas represents, on average for the whole peninsula, only $9 \%$ of the total NANI inputs, which means that a huge part of the $\mathrm{N}$ entering the territory is retained by diverse mechanisms on land.

Retention in the peninsula varies from $53 \%$ to $100 \%$, and values differ greatly between MED and TEMP catchments. Iberian TEMP basins present an average retention of $74 \%$. This is in agreement with the $70-80 \%$ retention that is commonly specified in the literature for North American and European rivers (e.g. Howarth et al., 1996, 2006; Boyer et al., 2002; Billen et al., 2011). In contrast, average retention in the Mediterranean is $92 \%$, and $\mathrm{N}$ retained is above $87 \%$ in most catchments.

Retention as considered herein includes diverse $\mathrm{N}$ removal processes affected by landscape properties. One of them is temperature. Warmer temperatures favour denitrification, which may increase the apparent retention in the watersheds (Schaefer \& Alber, 2007). Winter temperatures are similar in TEMP and MED basins (Fig. 2), but summer periods are on average $4-5^{\circ} \mathrm{C}$ warmer in MED areas $\left(17.4^{\circ} \mathrm{C}\right.$ and $22.2^{\circ} \mathrm{C}$, respectively). Warm Mediterranean summers are accompanied by low precipitation values. Rainfall in MED basins is roughly half the rainfall in TEMP basins throughout most of the year, but this value decreases to one-third during the summer months.

Partly due to these temperature and rainfall patterns, many Iberian rivers present a high degree of water regulation. Water management - including inter-basin water transfers, flow regulation in dams and reservoirs, and extensive networks of irrigation channels - is another important factor potentially influencing $\mathrm{N}$ retention. The Iberian Peninsula has one-fifth of all European reservoirs (Avakyan \& Iakovleva, 1998; Aristi et al., 2014) and has the largest number of dams per inhabitant and per land area in the world (García de Jalón, 2003). Data on the number of reservoirs, the volume of water stocked, their total capacity and the percentage of irrigated land per catchment are presented in Table 2. Note that these are low-end estimates, because most rivers are dotted with a large number of small weirs and ditches (roughly twice the number in Table 2), which we could not take into account due to lack of available information. 
Although unregistered weirs and ponds have a very limited storage capacity, they result in water diversions and interruptions in flow paths that alter the residence time in watersheds.

We used the data in Table 2 to calculate two indices of hydrologic alteration, namely the Impounded Runoff Index (IR) developed by Batalla et al. (2004) and the Indirect Alteration Index proposed by Belmar et al. (2013). The IR emphasises the effect of water infrastructures on river flow regimes and points directly at the enormous storage capacities set up in the past few decades to meet the increasing water demand for human and agricultural uses in the peninsula. According to Batalla et al. (2004), unimpaired rivers with natural flow conditions have IR=0; rivers with a few dams, where the regulatory capacity does not exceed the mean annual water yield (water stocked is effectively used on an annual cycle) show IR $<1$; and rivers with $\mathrm{IR}>1$ are subjected to strong flow regulation, with multi-year regulatory strategies to face long-term, persistent droughts. The latter is clearly the case in several Mediterranean streams, which show IR values well above 1 (and $>6$ if we consider their maximum storage capacity). In the Segura basin, the river outflow is so low that we have arbitrarily set the IR index to a maximum value of 10 and 15 (for live and total storage capacity, respectively). In contrast, very light or no regulation at all occurs in northern temperate catchments, where the index is at most 0.2 (or 0.29 taking into account the maximum reservoir capacity).

The IA Index weighs water storage data with the number of dams and the percentage of irrigated land per catchment, which is an indirect way to assess the effect of diversion channels and irrigation facilities. IA values $<6$ indicate reference or slightly altered conditions; IA values ranging from 6 to 12 indicate moderately altered rivers; and IA $>12$ refers to extremely altered rivers, with intense flow regulation through dams and reservoirs and substantial water abstraction for irrigation purposes. Coincident with the IR results, most Mediterranean streams are altered or extremely altered (the Tagus presents the highest IA value), while all but two temperate rivers are in (or close to) the reference state.

Using it as a proxy for the impact of reservoirs, we plotted the IR index against the percentage of retention in the catchments (Fig. 6). Removing those rivers that had no reservoirs at all (and hence with $\mathrm{IR}=0$ ), the two variables adjusted well to a logarithmic relationship and were highly correlated $\left(\mathrm{R}^{2}=0.5\right.$ using either the IR or the $\left.\mathrm{IR}_{\text {stocks }}\right)$. Interestingly, rivers with IR $<0.5$ showed a variable percentage of retention, while all rivers with IR $>0.5$ presented retention values over $90 \%$. We further plotted the percentage of irrigated land versus the retention to account for the effect of the channels (direct information on the length of the irrigation channels could not be obtained). Again, removing those catchments without irrigated land, we obtained a strong logarithmic relationship between the two variables; those catchments where at least $1 \%$ of the surface is irrigated systematically present retention values above $85 \%$.

\section{DISCUSSION}

According to these results, anthropogenic $\mathrm{N}$ inputs in the Iberian Peninsula, in either temperate or Mediterranean regions, are lower than the average values observed in most 
European catchments, and barely one-third of the $>10,000 \mathrm{~kg} \mathrm{~N} \mathrm{~km}^{-2} \mathrm{y}^{-1}$ reported for watersheds bordering the North Sea (Billen et al., 2011). There are two main N sources: in densely populated catchments, the import of $\mathrm{N}$ as food, and particularly as feed, is the dominant input, while the use of synthetic fertilisers is by far the main source in the rest of the Iberian watersheds.

Absolute NANI values are not the only difference with regard to other European countries. N inputs in the Iberian Peninsula have also evolved differently during the past few decades. Atmospheric emission and deposition of $\mathrm{N}$ oxides $\left(\mathrm{NO}_{\mathrm{x}}\right)$, for instance, have decreased in the majority of the EU countries, while they have increased in Spain and Portugal (Fagerli \& Aas, 2008). Mid-term historical trends of agricultural $\mathrm{N}$ inputs also differ from those in the rest of Europe, where intensive farming started long before and fertilisation rates have been progressively rationalised. In Spain and Portugal, despite a slight decline in the surface of land devoted to agriculture, the consumption of synthetic fertilisers and animal manure has increased over the past three decades, and growing trends are also observed for other intensification indicators, including the consumption of pesticides, the degree of mechanisation, the amount of irrigated lands or crop productivity (http://faostat.fao.org/; Lassaletta et al., 2014c).

Therefore, although in absolute terms $\mathrm{N}$ inputs are not as high as in other watersheds, Iberian $\mathrm{N}$ fluxes have not stabilised over time, and the high percentage of $\mathrm{N}$ retention in most parts of the peninsula implies that there is a large amount of $\mathrm{N}$ to be managed within the catchments. However, not all the incoming $\mathrm{N}$ is accumulated on land, for retention as defined herein includes $\mathrm{N}$ losses via denitrification in soils and streams, in wetlands and at wastewater treatment plants. Half of the $\mathrm{N}$ retained and subsequently eliminated could be a reasonable value. Van Breemen et al. (2002) estimated that denitrification could account for about $50 \%$ of the total retention in north-eastern US catchments, and in the Oglio River (northern Italy) Bartoli et al. (2012) set up maximum denitrification values of ca. $45 \%$ of the retained $\mathrm{N}$. Denitrification may be a major removal pathway, but the relative fluxes of denitrification, mineralisation and immobilisation of $\mathrm{N}$ on land are indeed poorly constrained. In a recent study in the Mississippi basin, Van Meter et al. (2016) discussed the uncertainty of these $\mathrm{N}$ fluxes and provided evidence of the importance of $\mathrm{N}$ accumulation in the soil organic matter pool (hitherto undervalued), which they estimated to reach over $40 \%$ of the $\mathrm{N}$ retained on land.

Whatever the case, high $\mathrm{N}$ retention values have serious implications in terms of $\mathrm{N}$ pollution of aquifers and freshwater streams as well as atmospheric emissions of greenhouse gases. In addition, according to Van Meter et al. (2016), $\mathrm{N}$ accumulation in soils - therein called the $\mathrm{N}$ legacy - may contribute to time lags in catchment response after changes in management practices. Determining whether high retention values are a mere consequence of climatic characteristics, e.g. Mediterranean here, or if water regulation issues are exacerbating the accumulation of $\mathrm{N}$ within the catchments/hydrographic network is therefore key in addressing current $\mathrm{N}$ management challenges, and to prevent future problems in areas with similar characteristics. 
Our data show that the fraction of $\mathrm{N}$ retained is much larger in Mediterranean than in temperate basins. High retention rates in MED basins are of particular concern, because (1) in many Mediterranean arid and semi-arid regions aquifers are a crucial resource and (2) arid and semi-arid regions can have large vadose zones (e.g. Walvoord et al. 2003), comprising a large water storage compartment, but this groundwater can be heavily exposed to nitrate pollution issues.

Climatic features. Climatic features have been put forward to explain divergent retention values in river catchments (e.g. Caraco \& Cole, 1999; Howarth et al., 2006, 2012; Schaefer \& Alber, 2007; Sobota et al., 2009) and they may be the basis of the high retention values found in the Mediterranean. Basically, climatic factors act directly upon two processes: (1) warm temperatures accelerate denitrification rates and (2) dry weather favours longer water residence times in the watershed, and hence allows for longer exposure of nitrates to denitrifying bacteria. Both effects are indeed intertwined, because arid and semi-arid regions tend to be both warm and dry.

The effect of temperature on denitrification rates was proposed by Schaefer \& Alber (2007) as the main mechanism explaining lower $\mathrm{N}$ export in warm than in colder temperate watersheds of the United States. These authors observed a breakpoint in the rate of denitrification at about $10-12^{\circ} \mathrm{C}$, which was consistent with previous studies on the metabolism of denitrifying communities. The range of temperatures in their study, however, was much larger than in our case. Mean annual temperatures in Iberian catchments range from 11.6 to $16.5^{\circ} \mathrm{C}$, and differences between TEMP and MED watersheds are small $\left(12.1^{\circ} \mathrm{C}\right.$ on average in TEMP basins, and $14.6^{\circ} \mathrm{C}$ in MED basins), which means that all the basins in our study would be included within the warm watersheds identified by Schaefer \& Alber (2007). Further, in the summer, when denitrification processes would be more efficient, all Iberian basins show temperatures above $17^{\circ} \mathrm{C}$.

Consequently, although we agree that temperature can accelerate $\mathrm{N}$ denitrification processes and can explain some variability in $\mathrm{N}$ retention between climatically contrasted regions, the 10$12^{\circ} \mathrm{C}$ threshold is surpassed in both our TEMP and MED basins, and we believe this factor alone cannot account for the large retention differences found in our study.

In contrast to Schaefer \& Alber (2007), Howarth et al. (2006) stressed the role of precipitation and discharge in the retention of $\mathrm{N}$, and suggested that higher retention rates in drier watersheds were mostly related to longer residence times. In particular, they argue that although greater denitrification rates would be expected in wetter environments, where soils are more likely to be waterlogged, $\mathrm{N}$ sinks are less efficient due to faster flushing of water through riparian wetlands and low-order streams. Similarly, Sobota et al. (2009) found that rainfall and runoff, rather than temperature, were the main predictors of $\mathrm{N}$ export and retention in Mediterranean-type catchments in the United States, and stated that the effects of temperature on controlling watershed $\mathrm{N}$ processing may be strongest where there is a relatively abundant water supply. 
Differences in precipitation and runoff are large between MED and TEMP watersheds in the Iberian Peninsula, so these two features can partly explain the disparity in retention values. Moreover, while rainfall in temperate catchments is regularly distributed throughout the wet season, Mediterranean climates are characterised by hot, dry summers, followed by few very intense rainfall episodes (Estrela et al., 2001). This irregular regime allows $\mathrm{N}$ to naturally accumulate in dry soils during long periods of time, but most importantly, the trigger of an indirect mechanism, in our opinion, is more important than the climatic characteristics per se: a generalised water flow regulation.

Reservoirs. Water flow regulation is intended to guarantee water supply for human consumption and agricultural uses, and to control for flood risks, and in the Iberian Peninsula it is performed through a dense network of dams and reservoirs, diversion canals for inter-basin water transfers, and countless numbers of weirs and irrigation channels (García de Jalón, 2003). These infrastructures, especially those associated with agricultural demands, have been shown to produce important changes in flow magnitude, variability and seasonality in Mediterranean rivers (Belmar et al., 2010; Lorenzo-Lacruz et al., 2012).

Reservoirs, particularly those with a large storage capacity, can drastically increase the residence time of the water within the watershed, favouring $\mathrm{N}$ assimilation by algae and denitrification processes within the sediments; they are thus effective N sinks (Garnier et al., 1999; 2000). Bartoli et al. (2012) suggested that the role of reservoirs as N sinks in rivers where the flow is tightly regulated is indeed essential, because the river no longer inundates the surrounding area, and therefore natural denitrification spots such as riparian wetlands rarely function. These authors point out that although wetland denitrification rates in Mediterranean regions can be potentially rather high, they are not too effective because the surface is limited, and their role is often times played by reservoirs.

In addition, it is acknowledged that the effects of reservoirs on the flow regime are more pronounced in Mediterranean than in temperate zones, mainly because the former have greater storage needs (and capacity) to face naturally scarce water resources (López-Moreno et al., 2009; Lorenzo-Lacruz et al., 2010). In the Ebro Basin, for instance, floods were found to be more affected by reservoirs in its southern Mediterranean tributaries than those in the Atlantic zone, even with similar impoundment levels (Batalla et al., 2004).

The strong effect of reservoirs (both in number and storage capacity) stands out clearly in our results. The relationship between the IR Index and the percentage of $\mathrm{N}$ retention shows that when the regulatory capacity is limited (IR<0.5), as occurs in temperate catchments, $\mathrm{N}$ retention is variable and likely dependent on several different factors, but under multiyear regulatory strategies (IR $>0.5$, and specially IR $>1$ ), $\mathrm{N}$ retention in the watershed is always $>90 \%$.

Powers et al. (2015) gave further evidence on the importance of reservoirs for $\mathrm{N}$ retention, particularly when they are located in agricultural landscapes, and emphasised that, unlike natural lakes, this type of constructed reservoir tends to be highly connected to surface water flows, and the hydrologic connectivity between sources and sinks fosters an efficient turnover of 
nutrients. Moreover, the influence of dams and reservoirs on $\mathrm{N}$ assimilation may not be restricted to the water masses stocked within them. In a recent study, Aristi et al. (2014) showed how dams can lead to increases in primary production rates (including higher nitrate consumption) in flow-regulated rivers with regard to unregulated streams, not only within the reservoirs but also downstream.

Irrigation systems. The effect of irrigation on $\mathrm{N}$ retention is closely related to that described for reservoirs, partly because irrigation systems are inevitably accompanied by dams and weirs, and partly because extensive irrigation networks tend to co-occur with reservoirs in those areas where water resources are limited. The specific effect of irrigation is nonetheless worth discussing on its own, because irrigation systems are expected to increase dramatically in the coming decades, notably in arid and semi-arid regions (Törnqvist et al., 2015).

Channels and ditches are used to redistribute and recirculate water, diverting it from the main stream. Broadly, the ramification of flow paths increases water residence time in the catchment and thus favours denitrification processes. In northern Italy, Bartoli et al. (2012) noted that denitrification in the irrigation network accounted for a large part of the $\mathrm{N}$ retained in the watershed. Likewise, high water recirculation ratios (which ultimately suppose an extension in the length of the flow paths) caused a significant increase in $\mathrm{N}$ retention in a semiarid basin in Central Asia (Törnqvist et al., 2015).

Traditional irrigation practices based on soil flooding increase the contact surface of water and promote the processing of $\mathrm{N}$ by denitrifiers, and when flooding is performed over permeable land, $\mathrm{N}$ leaching to underground waters may be also very intense, adding to the overall $\mathrm{N}$ retention. In more efficient irrigation systems, off-site $\mathrm{N}$ concentrations and $\mathrm{N}$ leaching to adjacent rivers and aquifers are remarkably reduced, but $\mathrm{N}$ concentrations in the irrigation return fluxes are higher (Causapé et al., 2006; García-Garizábal et al., 2010) and this allows for heightened denitrification within the channels.

Our results are fully consistent with this reasoning. Figure 6 shows that, above a threshold of $1 \%$ of irrigated land (the percentage of irrigation ranges from 0 to $7 \%$, Table 2), the retention in the catchments is $>85 \%$. The effect of irrigation is similar to that observed for the reservoirs, which points at (1) the co-occurrence of both factors in the catchments, and (2) the similarity/interrelation in the mechanisms operating on $\mathrm{N}$ retention in both cases, that is, increased contact surface and increased water residence time.

Aside from the discussed consequences on $\mathrm{N}$ retention, extreme channelisation and large numbers of dams and reservoirs alter the connectivity between aquatic systems and wetlands, and that has implications on many other landscape functions such as base flow chemistry, metal and pesticide immobilisation, sediment retention, carbon sequestration or biodiversity support (e.g. providing habitat or shelter, or favouring dispersion). In a recent study, Cohen et al. (2016) called for consideration of the environmental role of hydrologic connectivity, and urged an evaluation of the impact of those human activities that either decrease (e.g. dams/levees) or increase it (e.g. canals/ditches). 


\section{Conclusions}

We believe the difference in $\mathrm{N}$ retention between temperate and Mediterranean catchments in the Iberian Peninsula is mostly related to water management practices, notably to extreme flow regulation. Warm and dry conditions may favour higher denitrification rates in the Mediterranean regions, but this factor alone can hardly explain the large difference in retention. Our results show that reservoirs and irrigation channels account for $>50 \%$ of the variability in $\mathrm{N}$ retention values. Further, above a certain flow regulation threshold, $\mathrm{N}$ retention peaks to values over $85-90 \%$.

While in temperate catchments artificial ponds are proposed as an efficient way to increase $\mathrm{N}$ retention and avoid the discharge of nitrates from agricultural plots to nearby streams (Garnier et al., 2014; Passy et al., 2012; Arheimer \& Pers, 2016), in Mediterranean rivers too much flow intervention through ditches and weirs has led to disproportionate $\mathrm{N}$ retention and hence potential pollution problems in soils, the atmosphere, as well as subsurface and underground waters.

Future climate projections forecast a decrease in rainfall and increased evapotranspiration in the Iberian Peninsula (Rodriguez-Puebla \& Nieto, 2010) and in many regions of the world (IPCC, 2014; Trnka et al., 2011). Agricultural intensification and a net expansion of irrigation are also foreseen, particularly in arid and semi-arid systems (IPCC, 2014). Agricultural development may entail an increase in fertiliser use, and the combination of increased water scarcity and higher water needs will certainly lead to increased flow regulation. The situation can therefore resemble the conditions observed in the Mediterranean catchments studied herein, whose $\mathrm{N}$ dynamics has been shown to be substantially affected by flow regulation infrastructures. High $\mathrm{N}$ retention and the environmental risks associated with it must be considered as an important consequence of water regulation practices and must be adequately managed.

\section{ACKNOWLEDGEMENTS}

Dr. E. Romero acknowledges the support received from the Iberdrola Foundation through its Grants for Research in Energy and the Environment programme. The authors are especially grateful to Dr. Adrian Leip, who kindly provided spatialised data on synthetic fertilisers. We also thank the French RESET project (http://seineaval.crihan.fr/web/pages.jsp?currentNodeId=189), the Spanish ADEPT project (Aerosol Deposition and Ocean Plankton Dynamics, CTM2011-23458, Spanish Ministry of Science and Innovation) and the Fédération Île de France de Recherche en Environnement (FIRE) for providing financial support to Dr. E. Romero and Dr. L. Lassaletta. 


\section{REFERENCES}

Aguilera R, Marcé R, Sabater S. Detection and attribution of global change effects on river nutrient dynamics in a large Mediterranean basin. Biogeosciences 2015; 12: 4085-4098.

Álvarez-Cabria M, Barquín J, Peñas FJ. Modelling the spatial and seasonal variability of water quality for entire river networks: Relationships with natural and anthropogenic factors. Science of the Total Environment 2016; 545: 152-162.

Anglade J, Billen G, Garnier J. Relationships for estimating N2 fixation in legumes: incidence for $\mathrm{N}$ balance of legume-based cropping systems in Europe. Ecosphere 2015; 6 .

Arheimer B, Pers BC. Lessons learned? Effects of nutrient reductions from constructing wetlands in 1996-2006 across Sweden. Ecol. Eng. 2016, in press http://dx.doi.org/10.1016/j.ecoleng.2016.01.088

Aristi I, Arroita M, Larranaga A, Ponsati L, Sabater S, von Schiller D, et al. Flow regulation by dams affects ecosystem metabolism in Mediterranean rivers. Freshwater Biology 2014; 59: 1816-1829.

Avakyan AB, Iakovleva VB. Status of global reservoirs: The position in the late twentieth century. Lakes \& Reservoirs: Research \& Management 1998; 3: 45-52.

Bartoli M, Racchetti E, Delconte CA, Sacchi E, Soana E, Laini A, et al. Nitrogen balance and fate in a heavily impacted watershed (Oglio River, Northern Italy): in quest of the missing sources and sinks. Biogeosciences 2012; 9: 361-373.

Batalla RJ, Gomez CM, Kondolf GM. Reservoir-induced hydrological changes in the Ebro River basin (NE Spain). Journal of Hydrology 2004; 290: 117-136.

Behrendt H, Opitz D. Retention of nutrients in river systems: dependence on specific runoff and hydraulic load. Hydrobiologia 2000; 410: 111-122.

Belmar O, Bruno D, Martinez-Capel F, Barquin J, Velasco J. Effects of flow regime alteration on fluvial habitats and riparian quality in a semiarid Mediterranean basin. Ecological Indicators 2013; 30: 52-64.

Belmar O, Velasco J, Martinez-Capel F, Alberto Marin A. Natural flow regime, degree of alteration and environmental flows in the Mula stream (Segura River basin, SE Spain). Limnetica 2010; 29: 353-367.

Beman JM, Arrigo KR, Matson PA. Agricultural runoff fuels large phytoplankton blooms in vulnerable areas of the ocean. Nature 2005; 434: 211-214.

Billen G, Barles S, Garnier J, Rouillard J, Benoit P. The food-print of Paris: long-term reconstruction of the nitrogen flows imported into the city from its rural hinterland. Regional Environmental Change 2009b; 9: 13-24. 
Billen G, Beusen A, Bouwman L, Garnier J. Anthropogenic nitrogen autotrophy and heterotrophy of the world's watersheds: Past, present, and future trends. Global Biogeochemical Cycles 2010; 24.

Billen G, Silvestre M, Grizzetti B, Leip A, Garnier J, Voss M, Howarth R, Bouraoui F, et al. Nitrogen flows from European regional watersheds to coastal marine waters. In: Sutton MA, Howard CM, Erisman JW, Billen G, Bleeker A, Grennfelt P, et al., editors. The European Nitrogen Assessment. Cambridge University Press, New York, 2011, pp. 271-297.

Billen G, Thieu V, Garnier J, Silvestre M. Modelling the N cascade in regional watersheds: The case study of the Seine, Somme and Scheldt rivers. Agriculture Ecosystems \& Environment 2009a; 133: 234-246.

Bowman WD, Theodose TA, Fisk MC. Physiological and production responses of plant-growth forms to increases in limiting resources in alpine tundra - implications for differential community response to environmental change. Oecologia 1995; 101: 217-227.

Boyer EW, Goodale CL, Jaworsk NA, Howarth RW. Anthropogenic nitrogen sources and relationships to riverine nitrogen export in the northeastern USA. Biogeochemistry 2002; 57: 137-169.

Bruinsma J. The resource outlook to 2050: By how much do land, water use and crop yields need to increase by 2050? Expert Meeting on How to Feed the World in 2050. Rome: FAO and ESDD, 2009. ftp://ftp.fao.org/docrep/fao/o12/ak542e/ak542eo6.pdf

Camargo JA, Alonso A. Ecological and toxicological effects of inorganic nitrogen pollution in aquatic ecosystems: A global assessment. Environment International 2006; 32: 831-849.

Caraco NF, Cole JJ. Human impact on nitrate export: An analysis using major world rivers. Ambio 1999; 28: 167-170.

Caraco NF, Cole JJ. Human influence on nitrogen export: a comparison of mesic and xeric catchments. Marine and Freshwater Research 2001; 52: 119-125.

Causapé J, Quílez D, Aragüés R. Irrigation efficiency and quality of irrigation return flows in the Ebro River Basin: An overview. Environmental Monitoring and Assessment 2006; 117: 451461.

Cloern JE. Our evolving conceptual model of the coastal eutrophication problem. Marine Ecology-Progress Series 2001; 210: 223-253.

Cohen MJ, Creed IF, Alexander L, Basu NB, Calhoun AJK, Craft C, et al. Do geographically isolated wetlands influence landscape functions? Proceedings of the National Academy of Sciences of the United States of America 2016; 113: 1978-1986.

Crabtree RC, Bazzaz FA. Seedling response of 4 birch species to simulated nitrogen deposition Ammonium vs Nitrate. Ecological Applications 1993; 3: 315-321. 
Erisman JW, Sutton MA, Galloway J, Klimont Z, Winiwarter W. How a century of ammonia synthesis changed the world. Nature Geoscience 2008; 1: 636-639.

Estrela T, Menéndez M, Dimas M, Marcuello C, Rees G, Cole G, Weber K, Grath J, Leonard J, Ovesen NB, Fehér J, Consult V. Sustainable water use in Europe. Part 3. Extreme hydrological events: floods and droughts. Environmental Issue Report No. 21, EEA, Copenhagen, 84 pp, 2001.

Fagerli H, Aas W. Trends of nitrogen in air and precipitation: Model results and observations at EMEP sites in Europe, 1980-2003. Environmental Pollution 2008; 154: 448-461.

Galloway JN, Aber JD, Erisman JW, Seitzinger SP, Howarth RW, Cowling EB, et al. The nitrogen cascade. Bioscience 2003; 53: 341-356.

García de Jalón D. The Spanish experience in determining minimum flow regimes in regulated streams. Canadian Water Resources Journal 2003; 28: 185-198.

García-Garizábal I, Causapé J. Influence of irrigation water management on the quantity and quality of irrigation return flows. Journal of Hydrology 2010; 385: 36-43.

Garnier J, Beusen A, Thieu V, Billen G, Bouwman L. N:P:Si nutrient export ratios and ecological consequences in coastal seas evaluated by the ICEP approach. Global Biogeochemical Cycles $2010 ; 24$.

Garnier J, Billen G, Sanchez N, Leporcq B. Ecological functioning of the Marne reservoir (upper Seine basin, France). Regulated Rivers-Research \& Management 2000; 16: 51-71.

Garnier J, Billen G, Vilain G, Benoit M, Passy P, Tallec G, et al. Curative vs. preventive management of nitrogen transfers in rural areas: Lessons from the case of the Orgeval watershed (Seine River basin, France). Journal of Environmental Management 2014; 144: 125-134.

Garnier J, Leporcq B, Sanchez N, Philippon X. Biogeochemical mass-balances (C, N, P, Si) in three large reservoirs of the Seine Basin (France). Biogeochemistry 1999; 47: 119-146.

Goyette JO, Bennett EM, Howarth RW, Maranger R. Changes in anthropogenic nitrogen and phosphorus inputs to the St. Lawrence sub-basin over 110 years and impacts on riverine export. Global Biogeochemical Cycles 2016; doi: 10.1002/gbc.2043.

Grizzetti B, Bouraoui F, Billen G, van Grinsven H, Cardoso AC, Thieu V, et al. Nitrogen as a threat to European water quality. In: Sutton MA, Howard CM, Erisman JW, Billen G, Bleeker A, Grennfelt P, et al., editors. The European Nitrogen Assessment. Cambridge University Press, New York, 2011, pp. 379-404.

Gruber N, Galloway JN. An Earth-system perspective of the global nitrogen cycle. Nature 2008; 451: 293-296.

Henriksen A, Brakke DF. Increasing contributions of nitrogen to the acidity of surface waters in Norway. Water Air and Soil Pollution 1988; 42: 183-201. 
Herridge DF, Peoples MB, Boddey RM. Global inputs of biological nitrogen fixation in agricultural systems. Plant and Soil 2008; 311: 1-18.

Hong B, Swaney DP, Howarth RW. Estimating net anthropogenic nitrogen inputs to U.S. watersheds: Comparison of methodologies. Environmental Science \& Technology 2013; 47: 5199-5207.

Howarth R, Chan F, Conley DJ, Garnier J, Doney SC, Marino R, et al. Coupled biogeochemical cycles: eutrophication and hypoxia in temperate estuaries and coastal marine ecosystems. Frontiers in Ecology and the Environment 2011; 9: 18-26.

Howarth R, Swaney D, Billen G, Garnier J, Hong B, Humborg C, et al. Nitrogen fluxes from the landscape are controlled by net anthropogenic nitrogen inputs and by climate. Frontiers in Ecology and the Environment 2012; 10: 37-43.

Howarth RW, Billen G, Swaney D, Townsend A, Jaworski N, Lajtha K, et al. Regional nitrogen budgets and riverine N\&P fluxes for the drainages to the North Atlantic Ocean: Natural and human influences. Biogeochemistry 1996; 35: 75-139.

Howarth RW, Swaney DP, Boyer EW, Marino R, Jaworski N, Goodale C. The influence of climate on average nitrogen export from large watersheds in the Northeastern United States. Biogeochemistry 2006; 79: 163-186.

Intergovernmental Panel on Climate Change, IPCC. Climate Change 2014: Synthesis Report. Contribution of Working Groups I, II and III to the Fifth Assessment Report of the Intergovernmental Panel on Climate Change [Core Writing Team, R.K. Pachauri and L.A. Meyer (eds.)]. Geneva, Switzerland: IPCC, 2014. http://www.ipcc.ch/report/ar5/syr/

Lassaletta L, Billen G, Grizzetti B, Anglade J, Garnier J. 50-year trends in nitrogen use efficiency of world cropping systems: the relationship between yield and nitrogen input to cropland. Environmental Research Letters 2014a; 9: 105011.

Lassaletta L, Billen G, Grizzetti B, Garnier J, Leach AM, Galloway JN. Food and feed trade as a driver in the global nitrogen cycle: 50-year trends. Biogeochemistry 2014b; 118: 225-241.

Lassaletta L, Romero E, Billen G, Garnier J, García-Gómez H, Rovira JV. Spatialized N budgets in a large agricultural Mediterranean watershed: high loading and low transfer. Biogeosciences 2012; 9: 57-70.

Lassaletta L, Billen G, Romero E, Garnier J, Aguilera E. How changes in diet and trade patterns have shaped the N cycle at the national scale: Spain (1961-2009). Regional Environmental Change 2014c; 14: 785-797.

Leip A, Achermann B, Billen G, Bleeker A, Bouwman AF, de Vries W, et al. Integrating nitrogen fluxes at the European scale. In: Sutton MA, Howard CM, Erisman JW, Billen G, Bleeker A, Grennfelt P, et al., editors. The European Nitrogen Assessment. Cambridge University Press, New York, 2011, pp. 345-376. 
Lepistö A, Granlund K, Kortelainen P, Raike A. Nitrogen in river basins: Sources, retention in the surface waters and peatlands, and fluxes to estuaries in Finland. Science of the Total Environment 2006; 365: 238-259.

Lepistö A, Kenttamies K, Rekolainen S. Modeling combined effects of forestry, agriculture and deposition on nitrogen export in a northern river basin in Finland. Ambio 2001; 30: 338348.

Liquete C, Arnau P, Canals M, Colas S. Mediterranean river systems of Andalusia, southern Spain, and associated deltas: A source to sink approach. Marine Geology 2005; 222: 471-495. López-Moreno JI, Vicente-Serrano SM, Begueria S, García-Ruiz JM, Portela MM, Almeida AB. Dam effects on droughts magnitude and duration in a transboundary basin: The Lower River Tagus, Spain and Portugal. Water Resources Research 2009; 45.

Lorenzo-Lacruz J, Vicente-Serrano SM, Lopez-Moreno JI, Begueria S, Garcia-Ruiz JM, Cuadrat JM. The impact of droughts and water management on various hydrological systems in the headwaters of the Tagus River (central Spain). Journal of Hydrology 2010; 386: 13-26.

Lorenzo-Lacruz J, Vicente-Serrano SM, Lopez-Moreno JI, Moran-Tejeda E, Zabalza J. Recent trends in Iberian streamflows (1945-2005). Journal of Hydrology 2012; 414: 463-475.

Nixon SW. Coastal Marine Eutrophication - a Definition, Social Causes, and Future Concerns. Ophelia 1995; 41: 199-219.

OSPAR. Principles of the comprehensive study on riverine inputs and direct discharges (RID). OSPAR Commission, Reference number: 1998-5, 17 pp, 1998.

Pacheco FAL, Sanches Fernandes LF. Environmental land use conflicts in catchments: A major cause of amplified nitrate in river water. Science of the Total Environment 2016; 548: 173188.

Pacheco FAL, Santos RMB, Sanches Fernandes LF, Pereira MG, Cortes RMV. Controls and forecasts of nitrate yields in forested watersheds: A view over mainland Portugal. Science of the Total Environment 2015; 537: 421-440.

Passy P, Garnier J, Billen G, Fesneau C, Tournebize J. Restoration of ponds in rural landscapes: Modelling the effect on nitrate contamination of surface water (the Seine River Basin, France). Science of the Total Environment 2012; 430: 280-290.

Powers SM, Tank JL, Robertson DM. Control of nitrogen and phosphorus transport by reservoirs in agricultural landscapes. Biogeochemistry 2015; 124: 417-439.

Quynh LTP, Billen G, Garnier J, Thery S, Fezard C, Minh CV. Nutrient (N, P) budgets for the Red River basin (Vietnam and China). Global Biogeochemical Cycles 2005; 19.

Rockström J, Steffen W, Noone K, Persson A, Chapin FS, III, Lambin EF, et al. A safe operating space for humanity. Nature 2009; 461: 472-475. 
Rodriguez-Puebla C, Nieto S. Trends of precipitation over the Iberian Peninsula and the North Atlantic Oscillation under climate change conditions. International Journal of Climatology 2010; 30: 1807-1815.

Romero E, Garnier J, Lassaletta L, Billen G, Le Gendre R, Riou P, et al. Large-scale patterns of river inputs in southwestern Europe: seasonal and interannual variations and potential eutrophication effects at the coastal zone. Biogeochemistry 2013; 113: 481-505.

Schaefer SC, Alber M. Temperature controls a latitudinal gradient in the proportion of watershed nitrogen exported to coastal ecosystems. Biogeochemistry 2007; 85: 333-346.

Schulze ED. Air pollution and forest decline in a spruce (Picea abies) forest. Science 1989; 244: 776-783.

Smil V. Enriching the Earth: Fritz Haber, Carl Bosch, and the transformation of world food production. Cambridge, MA: Massachusetts Institute of Technology Press, 2001.

Sobota DJ, Harrison JA, Dahlgren RA. Influences of climate, hydrology, and land use on input and export of nitrogen in California watersheds. Biogeochemistry 2009; 94: 43-62.

Spalding RF, Exner ME. Occurrence of nitrate in groundwater - A review. Journal of Environmental Quality 1993; 22: 392-402.

Sutton MA, Howard CM, Erisman JW, Billen G, Bleeker A, Grennfelt P, et al. The European Nitrogen Assessment. New York: Cambridge University Press, 2011.

Törnqvist R, Jarsjo J, Thorslund J, Rao PSC, Basu NB, Destouni G. Mechanisms of Basin-Scale Nitrogen Load Reductions under Intensified Irrigated Agriculture. PLoS ONE 2015; 10.

Trnka M, Olesen JE, Kersebaum KC, Skjelvag AO, Eitzinger J, Seguin B, et al. Agroclimatic conditions in Europe under climate change. Global Change Biology 2011; 17: 2298-2318.

Van Breemen N, Boyer EW, Goodale CL, Jaworski NA, Paustian K, Seitzinger SP, et al. Where did all the nitrogen go? Fate of nitrogen inputs to large watersheds in the northeastern USA. Biogeochemistry 2002; 57: 267-293.

Van Meter KJ, Basu NB, Veenstra JJ, Burras CL. The nitrogen legacy: emerging evidence of nitrogen accumulation in anthropogenic landscapes. Environmental Research Letters 2016; 11.

Verhoff FH, Yaksich SM, Melfi DA. River nutrient and chemical-transport estimation. Journal of the Environmental Engineering Division-Asce 1980; 106: 591-608.

Walling DE, Webb BW. Estimating the discharge of contaminants to coastal waters by rivers: some cautionary comments. Marine Pollution Bulletin 1985; 16: 488-492.

Walvoord MA, Phillips FM, Stonestrom DA, Evans RD, Hartsough PC, Newman BD, et al. A reservoir of nitrate beneath desert soils. Science 2003; 302: 1021-1024. 


\section{TABLES AND FIGURES}

Table 1. The list of Iberian rivers analysed in the study with their corresponding catchment area and the mean annual flow for the 2000-2010 period. The final column indicates the water authorities that provided flow and water quality information.

\begin{tabular}{|c|c|c|c|c|}
\hline & River & $\begin{array}{l}\text { Catchment } \\
\operatorname{area}\left(\mathrm{km}^{2}\right)\end{array}$ & $\begin{array}{r}\text { Mean flow } \\
\left(\mathrm{Hm}^{3} \cdot \mathbf{y}^{-1}\right)\end{array}$ & Data source \\
\hline \multirow[t]{13}{*}{$M E D$} & Ter & 2964 & 364 & $\mathrm{ACA}^{\mathrm{a}}$ \\
\hline & Tordera & 780 & 80 & ACA \\
\hline & Besos & 1038 & 135 & $\mathrm{ACA}$ \\
\hline & Llobregat & 4924 & 338 & $\mathrm{ACA}$ \\
\hline & Ebro & 84542 & 8805 & $\mathrm{CEDEX}^{\mathrm{b}}, \mathrm{CH} \mathrm{Ebro}^{\mathrm{c}}$ \\
\hline & Jucar & 21548 & 481 & CEDEX, CH Júcar ${ }^{\mathrm{d}}$ \\
\hline & Segura & 14953 & 2 & CEDEX, CH Segura \\
\hline & Guadalquivir & 47244 & 2623 & CEDEX, CH Guadalquivirf \\
\hline & Guadiana & 61941 & 2147 & CEDEX, SNIRHg \\
\hline & Sado & 2950 & 179 & SNIRH \\
\hline & Tagus & 68347 & 9904 & CEDEX, SNIRH \\
\hline & Mondego & 4945 & 2194 & SNIRH \\
\hline & Douro & 96673 & 16961 & CEDEX, SNIRH \\
\hline \multirow[t]{25}{*}{$T E M P$} & Minho & 15537 & 10515 & CEDEX, SNIRH \\
\hline & Eo & 714 & 515 & CEDEX, CH Cantábrico ${ }^{\mathrm{h}}$ \\
\hline & Porcia & 134 & 94 & CEDEX, CH Cantábrico \\
\hline & Negro & 86 & 65 & CEDEX, CH Cantábrico \\
\hline & Esva & 416 & 293 & CEDEX, CH Cantábrico \\
\hline & Narcea & 1703 & 1360 & CEDEX, CH Cantábrico \\
\hline & Nalon & 2906 & 1679 & CEDEX, CH Cantábrico \\
\hline & Sella & 485 & 576 & CEDEX, CH Cantábrico \\
\hline & Pilona & 485 & 383 & CEDEX, CH Cantábrico \\
\hline & Bedon & 102 & 92 & CEDEX, CH Cantábrico \\
\hline & Deva & 653 & 402 & CEDEX, CH Cantábrico \\
\hline & Besaya & 483 & 358 & CEDEX, CH Cantábrico \\
\hline & Pas & 359 & 239 & CEDEX, CH Cantábrico \\
\hline & Miera & 160 & 140 & CEDEX, CH Cantábrico \\
\hline & Ason & 493 & 633 & CEDEX, CH Cantábrico \\
\hline & Aguera & 121 & 104 & CEDEX, CH Cantábrico \\
\hline & Herrerias & 257 & 125 & CEDEX, CH Cantábrico \\
\hline & Nervion & 1009 & 864 & CEDEX, CH Cantábrico \\
\hline & Artibay & 96 & 92 & CEDEX, CH Cantábrico \\
\hline & Deba & 458 & 379 & CEDEX, CH Cantábrico \\
\hline & Urola & 307 & 262 & CEDEX, CH Cantábrico \\
\hline & Oria & 799 & 821 & CEDEX, CH Cantábrico \\
\hline & Urumea & 216 & 267 & CEDEX, CH Cantábrico \\
\hline & Oyarzun & 37 & 48 & CEDEX, CH Cantábrico \\
\hline & Bidasoa & 675 & 616 & CEDEX, CH Cantábrico \\
\hline \multicolumn{3}{|c|}{ A (aca-web.gencat.cat/aca) } & \multicolumn{2}{|c|}{ e CH Segura (www.chsegura.es) } \\
\hline $\operatorname{EDEX}(\mathrm{ce}$ & flumen64.ced & x.es) & \multicolumn{2}{|c|}{${ }^{\mathrm{f}} \mathrm{CH}$ Guadalquivir (www.chguadalquivir.es) } \\
\hline H Ebro ( & v.chebro.es) & & \multicolumn{2}{|c|}{ g SNIRH (snirh.apambiente.pt) } \\
\hline H Júcar ( & w.chj.es) & & \multicolumn{2}{|c|}{ h $\mathrm{CH}$ Cantábrico (www.chcantabrico.es) } \\
\hline
\end{tabular}


Table 2. Irrigated surface area, number of reservoirs (N), mean water storage capacity (i.e. actual water stocks in the reservoirs) and maximum reservoir capacity for all Iberian rivers in the study. Reservoir stocks are average values for the 2000-2010 period. Data were obtained from the Spanish and Portuguese water authorities described in Table $1 . \mathrm{IR}_{\text {stocks }}$ refers to the Impounded Runoff Index calculated with the real water stocks in the reservoirs, and IR to the same index calculated with the maximum reservoir capacity; IA refers to the Indirect Alteration Index (see the Methods section for further details on the calculation of the indices).

\begin{tabular}{|c|c|c|c|c|c|c|c|c|c|}
\hline & River & $\begin{array}{c}\text { Irrigated } \\
\text { land } \\
\left(\mathbf{k m}^{2}\right)\end{array}$ & $\begin{array}{l}\text { Irrigated } \\
\text { land } \\
(\%)\end{array}$ & $\mathbf{N}$ & $\begin{array}{c}\text { Reservoir } \\
\text { stocks } \\
\left(\mathrm{Hm}^{3}\right)\end{array}$ & $\begin{array}{c}\text { Max. } \\
\text { capacity } \\
\left(\mathrm{Hm}^{3}\right)\end{array}$ & IR $_{\text {stocks }}$ & IR & IA \\
\hline \multirow[t]{13}{*}{$\overline{M E D}$} & Ter & 91 & 3.06 & 3 & 248 & 400 & 0.68 & 1.10 & 8 \\
\hline & Tordera & 14 & 1.82 & o & o & o & 0.00 & 0.00 & 2 \\
\hline & Besos & 24 & 2.28 & o & o & o & 0.00 & 0.00 & 3 \\
\hline & Llobregat & 18 & 0.37 & 3 & 132 & 213 & 0.39 & 0.63 & 6 \\
\hline & Ebro & 5589 & 6.61 & 71 & 4500 & 7407 & 0.51 & 0.84 & 16 \\
\hline & Jucar & 1240 & 5.75 & 32 & 1082 & 3346 & 2.25 & 6.96 & 13 \\
\hline & Segura & 674 & 4.51 & 19 & 365 & 1147 & 10.00 & 15.00 & 10 \\
\hline & Guadalquivir & 1545 & 3.27 & 61 & 3783 & 8253 & 1.44 & 3.15 & 13 \\
\hline & Guadiana & 2981 & 4.81 & 42 & 7370 & 13154 & 3.43 & 6.13 & 15 \\
\hline & Sado & 212 & 7.18 & 10 & 360 & 618 & 2.01 & 3.45 & 14 \\
\hline & Tagus & 2551 & 3.73 & 81 & 8151 & 13580 & 0.82 & 1.37 & 20 \\
\hline & Mondego & 6 & 0.11 & 8 & 390 & 508 & 0.18 & 0.23 & 7 \\
\hline & Douro & 4520 & 4.68 & 53 & 5179 & 8990 & 0.31 & 0.53 & 14 \\
\hline \multirow[t]{25}{*}{ TEMP } & Minho & 6 & 0.04 & 35 & 1919 & 3045 & 0.18 & 0.29 & 8 \\
\hline & Eo & o & 0.00 & o & o & o & 0.00 & 0.00 & o \\
\hline & Porcia & o & 0.00 & $\mathrm{O}$ & o & o & 0.00 & 0.00 & o \\
\hline & Negro & o & 0.00 & o & o & o & 0.00 & 0.00 & o \\
\hline & Esva & o & 0.00 & $\mathrm{O}$ & o & o & 0.00 & 0.00 & o \\
\hline & Narcea & o & 0.00 & 2 & 21 & 34 & 0.02 & 0.02 & 2 \\
\hline & Nalon & 3 & 0.09 & 4 & 30 & 40 & 0.02 & 0.02 & 6 \\
\hline & Sella & 1 & 0.24 & o & o & o & 0.00 & 0.00 & 2 \\
\hline & Pilona & o & 0.10 & o & o & o & 0.00 & 0.00 & 1 \\
\hline & Bedon & o & 0.00 & o & o & o & 0.00 & 0.00 & o \\
\hline & Deva & o & 0.00 & o & o & o & 0.00 & 0.00 & o \\
\hline & Besaya & o & 0.00 & 1 & 11 & 33 & 0.03 & 0.09 & 2 \\
\hline & Pas & o & 0.00 & o & o & o & 0.00 & 0.00 & o \\
\hline & Miera & o & 0.00 & o & o & o & 0.00 & 0.00 & o \\
\hline & Ason & o & 0.00 & o & o & o & 0.00 & 0.00 & o \\
\hline & Aguera & o & 0.00 & o & o & o & 0.00 & 0.00 & o \\
\hline & Herrerias & o & 0.00 & o & o & o & 0.00 & 0.00 & o \\
\hline & Nervion & o & 0.00 & 2 & 17 & 22 & 0.02 & 0.03 & 2 \\
\hline & Artibay & o & 0.00 & o & o & o & 0.00 & 0.00 & o \\
\hline & Deba & o & 0.00 & o & o & o & 0.00 & 0.00 & o \\
\hline & Urola & o & 0.00 & o & o & o & 0.00 & 0.00 & o \\
\hline & Oria & o & 0.00 & 3 & 7 & 14 & 0.01 & 0.02 & 2 \\
\hline & Urumea & o & 0.00 & 1 & 34 & 44 & 0.13 & 0.16 & 3 \\
\hline & Oyarzun & o & 0.00 & o & o & o & 0.00 & 0.00 & o \\
\hline & Bidasoa & O & 0.00 & 0 & o & O & 0.00 & 0.00 & O \\
\hline
\end{tabular}


Table 3. Population (inhab $\left.\cdot \mathrm{km}^{-2}\right), \mathrm{N}$ fluxes $\left(\mathrm{kg} \mathrm{N} \cdot \mathrm{km}^{-2} \cdot \mathrm{y}^{-1}\right)$ and the corresponding percentage of retention for the two appointed groups (Mediterranean and temperate) and for all the Iberian catchments in the study. Data are area-weighted averages; the specific data per catchment are given in the Supplementary material.

\begin{tabular}{|c|c|c|c|c|}
\hline & Units & MED & TEMP & $\begin{array}{c}\text { All Iberian } \\
\text { basins }\end{array}$ \\
\hline Population density & inhab $\cdot \mathrm{km}^{-2}$ & 56 & 65 & 57 \\
\hline Synthetic fertilisers & $\mathrm{kg} \mathrm{N} \cdot \mathrm{km}^{-2} \cdot \mathrm{y}^{-1}$ & 2441 & 1199 & 2360 \\
\hline Biological N fixation & $\mathrm{kg} \mathrm{N} \cdot \mathrm{km}^{-2} \cdot \mathrm{y}^{-1}$ & 340 & 786 & 369 \\
\hline Total production & $\mathrm{kg} \mathrm{N} \cdot \mathrm{km}^{-2} \cdot \mathrm{y}^{-1}$ & 1582 & 1528 & 1578 \\
\hline Animal feed demand & $\mathrm{kg} \mathrm{N} \cdot \mathrm{km}^{-2} \cdot \mathrm{y}^{-1}$ & 1492 & 2580 & 1563 \\
\hline Human food demand & $\mathrm{kg} \mathrm{N} \cdot \mathrm{km}^{-2} \cdot \mathrm{y}^{-1}$ & 329 & 380 & 332 \\
\hline Net import & $\mathrm{kg} \mathrm{N} \cdot \mathrm{km}^{-2} \cdot \mathrm{y}^{-1}$ & 239 & 1433 & 317 \\
\hline $\mathrm{NO}_{\mathrm{x}}$ deposition & $\mathrm{kg} \mathrm{N} \cdot \mathrm{km}^{-2} \cdot \mathrm{y}^{-1}$ & 287 & 425 & 296 \\
\hline $\mathrm{NH}_{3}$ deposition & $\mathrm{kg} \mathrm{N} \cdot \mathrm{km}^{-2} \cdot \mathrm{y}^{-1}$ & -222 & -210 & -221 \\
\hline Net atm. $\mathrm{N}$ deposition & $\mathrm{kg} \mathrm{N} \cdot \mathrm{km}^{-2} \cdot \mathrm{y}^{-1}$ & 65 & 215 & 75 \\
\hline NANI & $\mathrm{kg} \mathrm{N} \cdot \mathrm{km}^{-2} \cdot \mathrm{y}^{-1}$ & 3085 & 3632 & 3121 \\
\hline River export & $\mathrm{kg} \mathrm{N} \cdot \mathrm{km}^{-2} \cdot \mathrm{y}^{-1}$ & 242 & 941 & 287 \\
\hline Retention & $\%$ & 92\% & $74 \%$ & $91 \%$ \\
\hline
\end{tabular}


Table S1. Summary of the data sources used in the study to calculate all input and output N fluxes.

\begin{tabular}{|c|c|c|}
\hline & Sources & Type of data \\
\hline Synthetic fertilisers & CAPRI model 2002; Leip et al., 2011 & Spatialised data on fertilisers' use \\
\hline \multirow[t]{3}{*}{ Biological N fixation } & EUROSTAT (http://ec.europa.eu/eurostat) & $\begin{array}{l}\mathrm{N} \text {-fixing crops and grasslands } \\
\text { (area, crop characteristics) }\end{array}$ \\
\hline & Anglade et al., 2015; Lassaletta et al., 2014a & BNF calculation formula \\
\hline & Herridge et al., 2008 & BNF values for rice \\
\hline Atmospheric deposition & EMEP (www.emep.int) & $\begin{array}{l}\text { Spatialised data on } \mathrm{NO}_{\mathrm{x}} \text { and } \mathrm{NH}_{3} \\
\text { deposition / emission }\end{array}$ \\
\hline \multirow[t]{2}{*}{ Total production } & EUROSTAT (http://ec.europa.eu/eurostat) & $\begin{array}{l}\text { Crop productivity and surface } \\
\text { area }\end{array}$ \\
\hline & Lassaletta et al., 2014b & $\begin{array}{l}\mathrm{N} \text { content of the agricultural } \\
\text { products }\end{array}$ \\
\hline \multirow[t]{2}{*}{ Animal stocks } & EUROSTAT (http://ec.europa.eu/eurostat) & Livestock data for Portugal \\
\hline & $\begin{array}{l}\text { Spanish Ministry of Agriculture } \\
\text { (www.magrama.gob.es) }\end{array}$ & Livestock data for Spain \\
\hline Animal excretion rates & $\begin{array}{l}\text { UN national inventories } \\
\text { (http://newsroom.unfccc.int) }\end{array}$ & Animal excretion factors \\
\hline \multirow[t]{2}{*}{ Human food demand } & EUROSTAT (http://ec.europa.eu/eurostat) & Inhabitants; population density \\
\hline & $\begin{array}{l}\text { FAOSTAT food balance sheets } \\
\text { (http://faostat3.fao.org) }\end{array}$ & Protein supply \\
\hline River export & $\begin{array}{l}\text { Several water authorities from Spain and } \\
\text { Portugal (details in Table 1) }\end{array}$ & $\begin{array}{l}\text { Daily river flow, monthly water } \\
\text { quality data }\end{array}$ \\
\hline
\end{tabular}




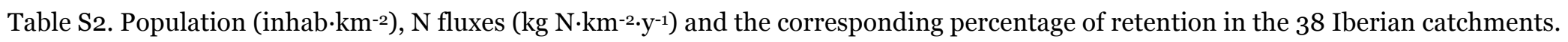

\begin{tabular}{|c|c|c|c|c|c|c|c|c|c|c|c|c|c|}
\hline & $\begin{array}{r}\text { Population } \\
\text { density }\end{array}$ & $\begin{array}{l}\text { Synthetic } \\
\text { fertilisers }\end{array}$ & $\begin{array}{r}\text { Biol. N } \\
\text { fixation } \\
\end{array}$ & $\begin{array}{r}\text { Total } \\
\text { production }\end{array}$ & $\begin{array}{r}\text { Animal } \\
\text { feed }\end{array}$ & $\begin{array}{r}\text { Human } \\
\text { food }\end{array}$ & $\begin{array}{r}\text { Net } \\
\text { import }\end{array}$ & $\begin{array}{l}\mathrm{NO}_{\mathrm{x}} \\
\text { dep. }\end{array}$ & $\begin{array}{l}\mathrm{NH}_{3} \\
\text { dep. }\end{array}$ & $\begin{array}{r}\text { Net atm. } \mathrm{N} \\
\text { dep. }\end{array}$ & NANI & $\begin{array}{r}\text { River } \\
\text { export }\end{array}$ & $\begin{array}{r}\% \\
\text { Retention } \\
\end{array}$ \\
\hline Ter & 126 & 1434 & 625 & 1399 & 5801 & 738 & 5139 & 742 & -211 & 531 & 7730 & 562 & $93 \%$ \\
\hline Tordera & 109 & 745 & 358 & 780 & 1359 & 637 & 1216 & 811 & -343 & 468 & 2788 & 371 & $87 \%$ \\
\hline Besos & 1351 & 1074 & 438 & 1105 & 3012 & 7900 & 9807 & 867 & -551 & 315 & 11634 & 510 & $96 \%$ \\
\hline Llobregat & 202 & 1192 & 421 & 1065 & 2864 & 1179 & 2978 & 604 & -678 & -74 & 4518 & 262 & $94 \%$ \\
\hline Ebro & 35 & 2273 & 541 & 1852 & 2121 & 204 & 473 & 383 & -288 & 95 & 3382 & 301 & $91 \%$ \\
\hline Jucar & 38 & 2420 & 140 & 1331 & 586 & 220 & -524 & 325 & -109 & 216 & 2252 & 115 & $95 \%$ \\
\hline Segura & 74 & 1483 & 102 & 956 & 1207 & 430 & 681 & 322 & -383 & -61 & 2205 & 1 & $100 \%$ \\
\hline Guadalquivir & 53 & 2628 & 157 & 1389 & 876 & 308 & -205 & 245 & -197 & 48 & 2628 & 276 & $89 \%$ \\
\hline Guadiana & 25 & 3084 & 332 & 1615 & 1299 & 147 & -169 & 213 & -213 & -1 & 3247 & 54 & $98 \%$ \\
\hline Sado & 17 & 2845 & 706 & 2432 & 1178 & 106 & -1147 & 243 & -190 & 54 & 2457 & 80 & $97 \%$ \\
\hline Tagus & 114 & 1802 & 222 & 1064 & 1401 & 669 & 1005 & 254 & -156 & 97 & 3127 & 252 & $92 \%$ \\
\hline Mondego & 91 & 873 & 58 & 433 & 1149 & 564 & 1280 & 286 & -64 & 221 & 2432 & 1101 & $55 \%$ \\
\hline Douro & 32 & 2879 & 413 & 2013 & 1488 & 187 & -338 & 241 & -211 & 30 & 2985 & 298 & $90 \%$ \\
\hline Minho & 45 & 1444 & 707 & 1154 & 2477 & 265 & 1587 & 305 & -278 & 27 & 3765 & 1060 & $72 \%$ \\
\hline Eo & 12 & 753 & 535 & 783 & 2296 & 73 & 1587 & 410 & -355 & 55 & 2930 & 1365 & $53 \%$ \\
\hline Porcia & 12 & 684 & 736 & 1666 & 5452 & 71 & 3857 & 417 & -176 & 241 & 5518 & 1146 & $79 \%$ \\
\hline Negro & 18 & 914 & 805 & 1822 & 3793 & 107 & 2078 & 458 & -31 & 427 & 4224 & 542 & $87 \%$ \\
\hline Esva & 16 & 658 & 905 & 2048 & 4893 & 92 & 2937 & 451 & -88 & 363 & 4864 & 975 & $80 \%$ \\
\hline Narcea & 17 & 549 & 834 & 1888 & 2613 & 97 & 823 & 470 & -220 & 250 & 2456 & 466 & $81 \%$ \\
\hline Nalon & 159 & 744 & 1202 & 2706 & 2238 & 932 & 465 & 666 & -168 & 498 & 2908 & 331 & $89 \%$ \\
\hline Sella & 7 & 659 & 407 & 898 & 1592 & 43 & 737 & 515 & -96 & 419 & 2222 & 632 & $72 \%$ \\
\hline Pilona & 34 & 855 & 1259 & 2831 & 3300 & 199 & 668 & 592 & -92 & 501 & 3283 & 733 & $78 \%$ \\
\hline Bedon & 15 & 547 & 737 & 1667 & 3742 & 89 & 2164 & 664 & 57 & 722 & 4169 & 554 & $87 \%$ \\
\hline Deva & 10 & 465 & 486 & 1099 & 1757 & 57 & 715 & 535 & -51 & 484 & 2149 & 325 & $85 \%$ \\
\hline Besaya & 127 & 688 & 894 & 2023 & 4381 & 741 & 3099 & 559 & -291 & 268 & 4949 & 733 & $85 \%$ \\
\hline Pas & 20 & 824 & 1170 & 2647 & 4148 & 116 & 1617 & 463 & -181 & 282 & 3893 & 871 & $78 \%$ \\
\hline Miera & 22 & 1196 & 1081 & 2446 & 5260 & 126 & 2940 & 577 & -52 & 525 & 5741 & 2149 & $63 \%$ \\
\hline Ason & 19 & 1230 & 1145 & 2590 & 5363 & 108 & 2881 & 620 & -38 & 582 & 5838 & 1361 & $77 \%$ \\
\hline Aguera & 18 & 1084 & 766 & 1734 & 2815 & 104 & 1186 & 640 & -31 & 609 & 3645 & 773 & $79 \%$ \\
\hline Herrerias & 29 & 1829 & 759 & 1805 & 2912 & 167 & 1274 & 698 & -25 & 673 & 4535 & 943 & $79 \%$ \\
\hline Nervion & 213 & 1026 & 767 & 1736 & 1950 & 1245 & 1459 & 677 & -30 & 647 & 3900 & 1571 & $60 \%$ \\
\hline Artibay & 67 & 904 & 745 & 1686 & 1977 & 391 & 682 & 582 & 73 & 655 & 2986 & 693 & $77 \%$ \\
\hline Deba & 266 & 667 & 661 & 1497 & 1468 & 1552 & 1523 & 554 & -52 & 502 & 3353 & 391 & $88 \%$ \\
\hline Urola & 170 & 1146 & 854 & 1932 & 2853 & 997 & 1918 & 572 & 45 & 617 & 4535 & 1471 & $68 \%$ \\
\hline Oria & 134 & 1204 & 873 & 1980 & 2918 & 781 & 1719 & 550 & -39 & 510 & 4307 & 1686 & $61 \%$ \\
\hline Urumea & 6 & 1627 & 58 & 132 & 1256 & 34 & 1158 & 548 & -110 & 438 & 3281 & 885 & $73 \%$ \\
\hline Oyarzun & 186 & 1253 & 860 & 1946 & 2159 & 1084 & 1298 & 544 & -117 & 427 & 3838 & 1117 & $71 \%$ \\
\hline Bidasoa & 32 & 2382 & 723 & 1760 & 2063 & 187 & 490 & 545 & -117 & 428 & 4023 & 908 & $77 \%$ \\
\hline
\end{tabular}




\section{Figure captions}

Figure 1. Map of the Iberian Peninsula showing the 38 river catchments included in the study and their corresponding annual discharge (blue circles). Top and bottom plots show the average flow of some representative rivers (the black line is the mean flow and the shaded area indicates \pm 1 standard deviation).

Figure 2. Monthly averages of temperature $\left({ }^{\circ} \mathrm{C}\right)$, precipitation $(\mathrm{mm})$ and surface runoff $(\mathrm{mm})$ in Mediterranean (MED, brown) and temperate (TEMP, green) catchments. The thick lines represent the mean, and the shaded area shows \pm 1 standard deviation. In accordance, catchments featuring Mediterranean characteristics are coloured in light brown on the map, while those corresponding to temperate climate are coloured in green.

Figure 3. A composite of the spatialised NANI terms (2000-2010 average).

Figure 4. River export and $\mathrm{N}$ retention (in \% and absolute values) in the 38 Iberian catchments.

Figure 5. NANI inputs versus river exports in MED (brown) and TEMP (green) catchments, and the corresponding linear relationships.

Figure 6. Retention versus log (IR index), and Retention versus log (\% irrigation). The white dots indicate those catchments with IR $=\mathrm{o}$ (left plot) and \% irrigation $=\mathrm{o}$ (right plot). 
Temperate rivers, $\mathbf{Q}\left(\mathrm{m}^{3} / \mathrm{s}\right)$
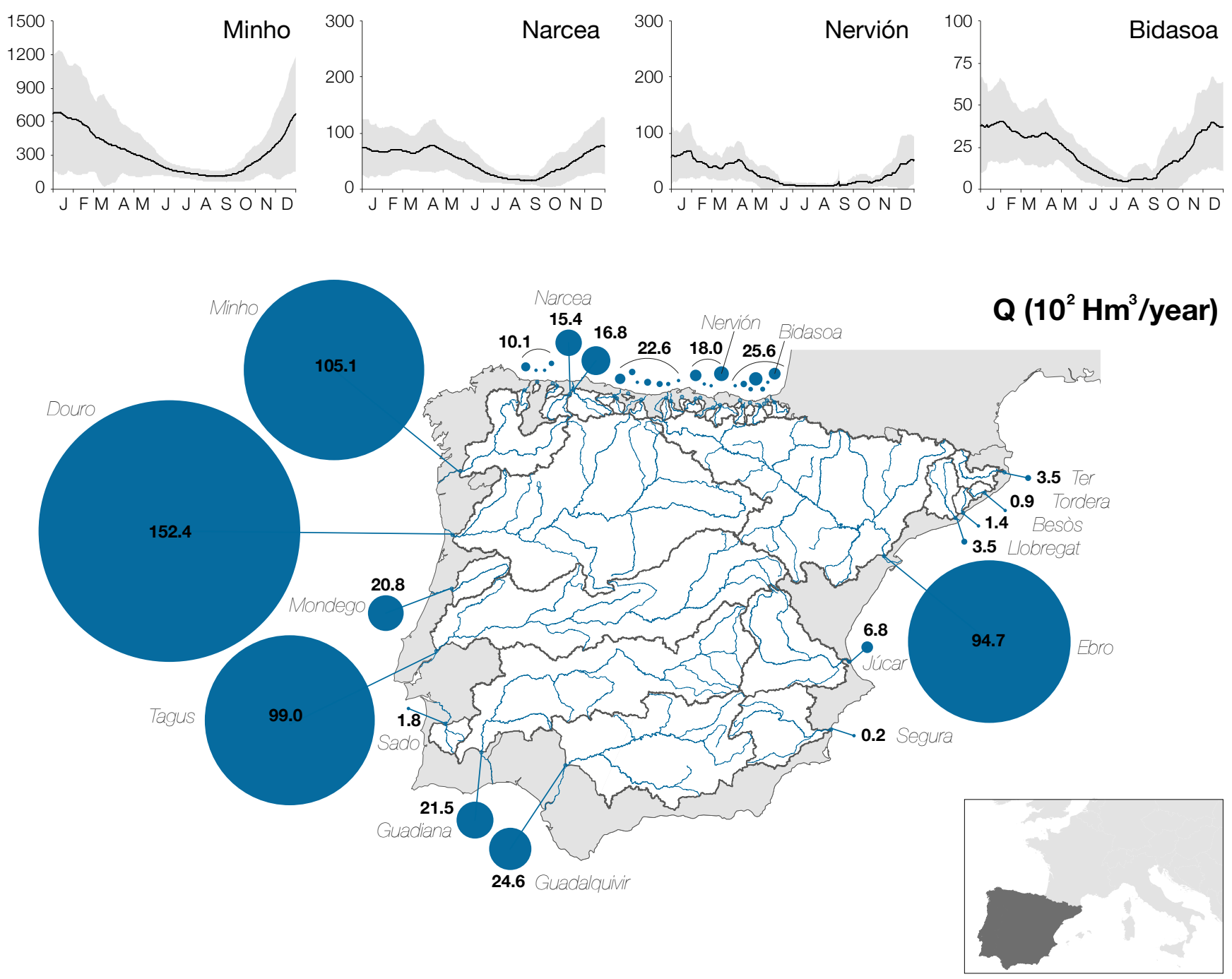

Mediterranean rivers, $Q\left(\mathrm{~m}^{3} / \mathrm{s}\right)$
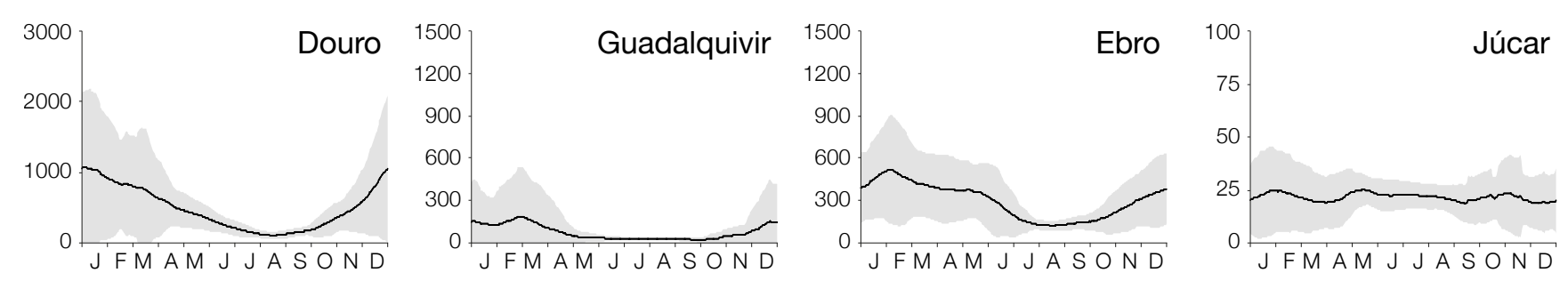

Fig. 1 


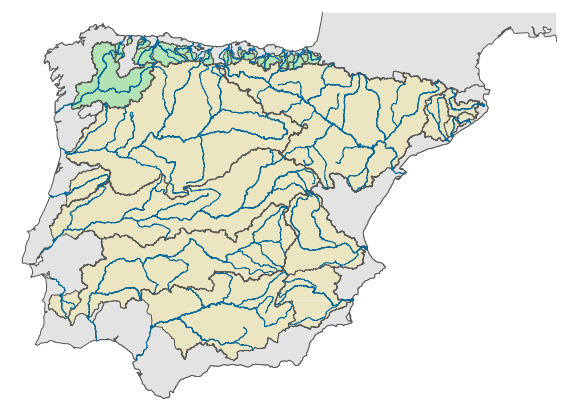

Temperature $\left({ }^{\circ} \mathrm{C}\right)$

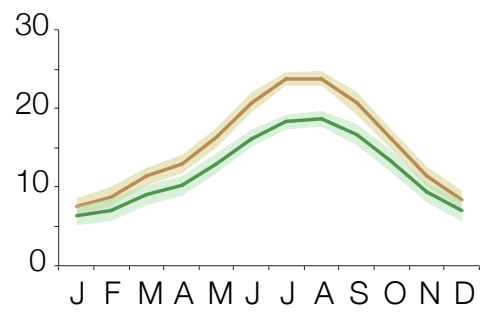

Rainfall (mm)

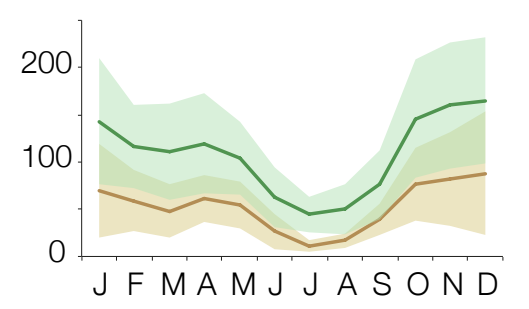

\section{Surface Runoff (mm)}

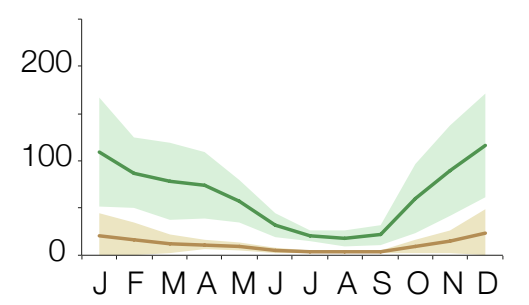

Fig. 2 
(a) Land use

CLC

Categories

$\square$ Crops

$\square$ Grass M

Mixed

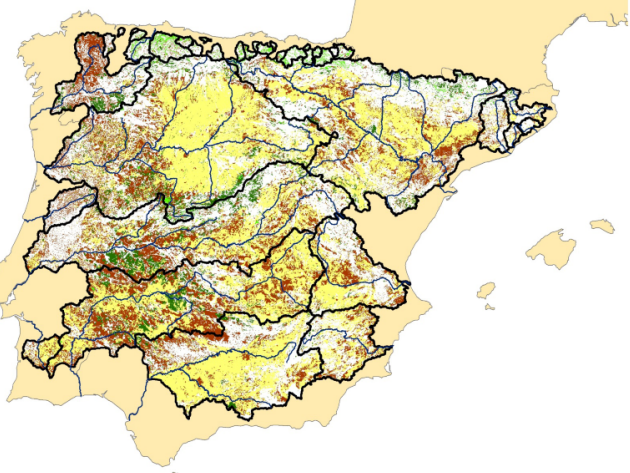

(d) Deposition NOx

$\mathrm{NO}_{\mathrm{x}}$ Deposition
$\left(\mathbf{k g ~ N} \cdot \mathbf{k m}^{-2} \cdot \mathrm{y}^{-1}\right)$

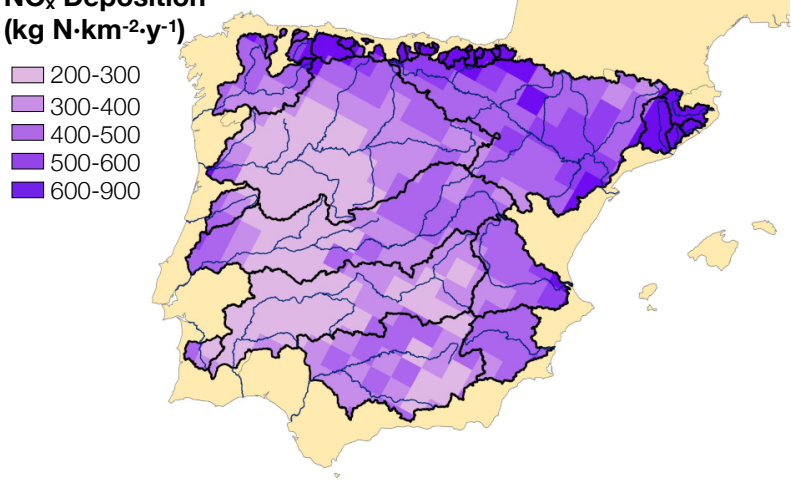

(g) Human demand

Human demand
$\left(\mathbf{k g ~ N} \cdot \mathrm{km}^{-2} \cdot \mathrm{y}^{-1}\right)$

(kg N.km

$\square$ 60-100

$\square$ 100-200

$\square 200-400$

$\square>500$

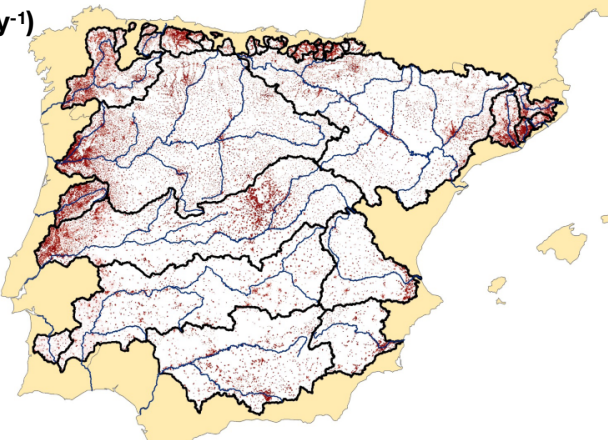

(b) Synthetic fertilisers

Synth. fertilisers

(kg N.km-2. $\mathbf{y}^{-1}$

$\square<1250$
$\square<4000$

$\square<4000$
$\square<9000$

$\square<16000$

$<90000$

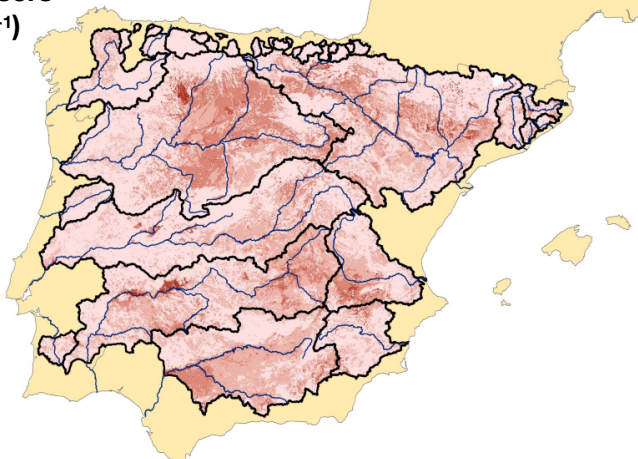

(e) Deposition $\mathrm{NH}_{3}$

\section{$\mathrm{NH}_{3}$ Deposition}

(kg N·km-2. $\mathbf{y}^{-1}$ )

$\square-1200--200$

$\square-200-100$

$\square$ 0-100

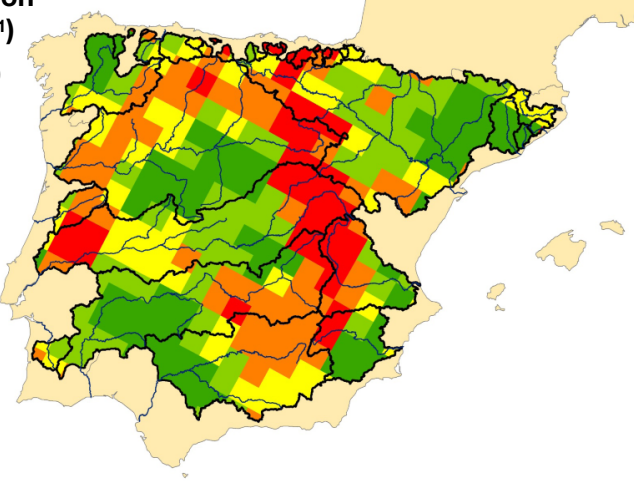

(h) Animal demand

Animal demand

(kg N.km-2.'-1)

0-100

0
$100-400$
$400-900$

$400-900$
$-900-1800$

$900-1800$
$1800-3500$

[ $>3500$

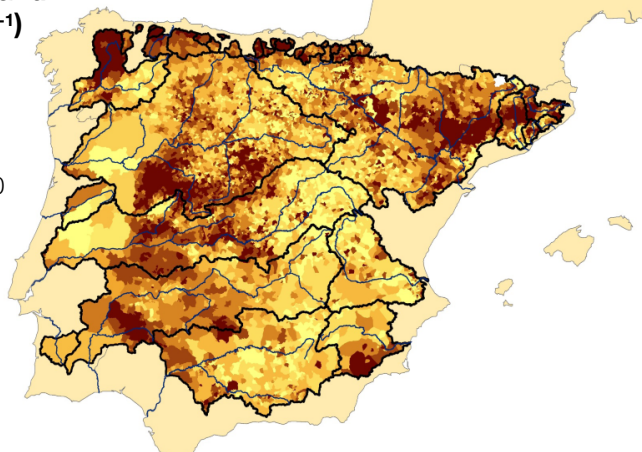

(c) Biological $\mathrm{N}$ fixation

Bio. N Fixation

(kg N.km ${ }^{-2} \cdot \mathbf{y}^{-1}$ )

$\square<200$

$\square<400$
$\square<800$

$\square<2500$

$\square<3600$

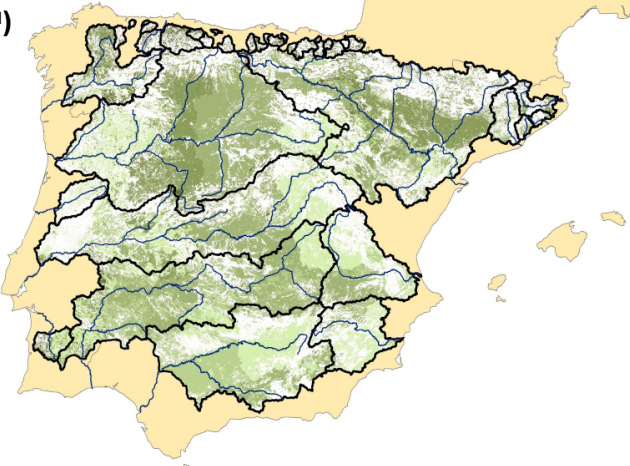

(f) Crop production

Crop production

(kg N.km-2.y-)

$\square<1000$

$\square<2200$

$\square<3200$
$\square<5200$

$\square<8000$

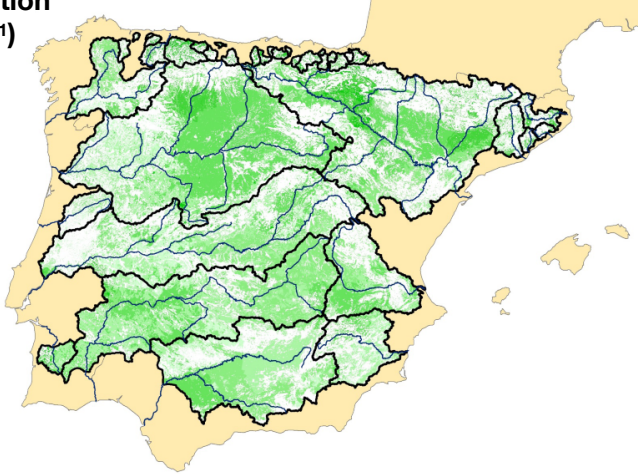

(i) NANI

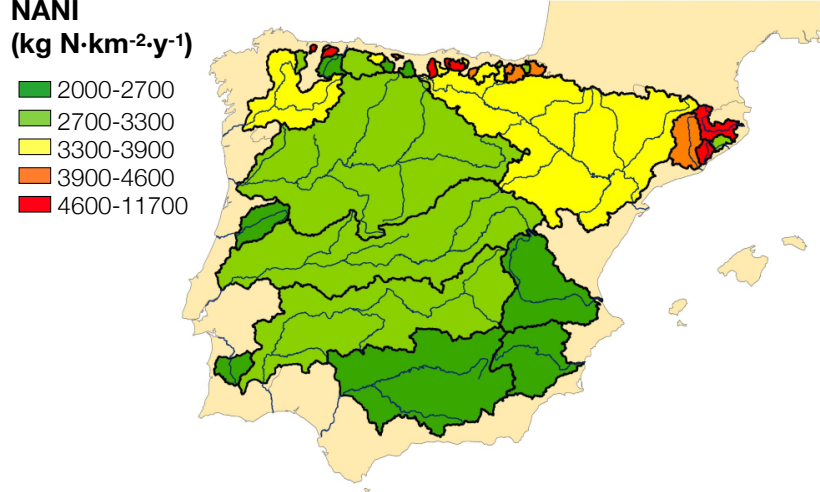

Fig. 3 
River export (Gg N/year)

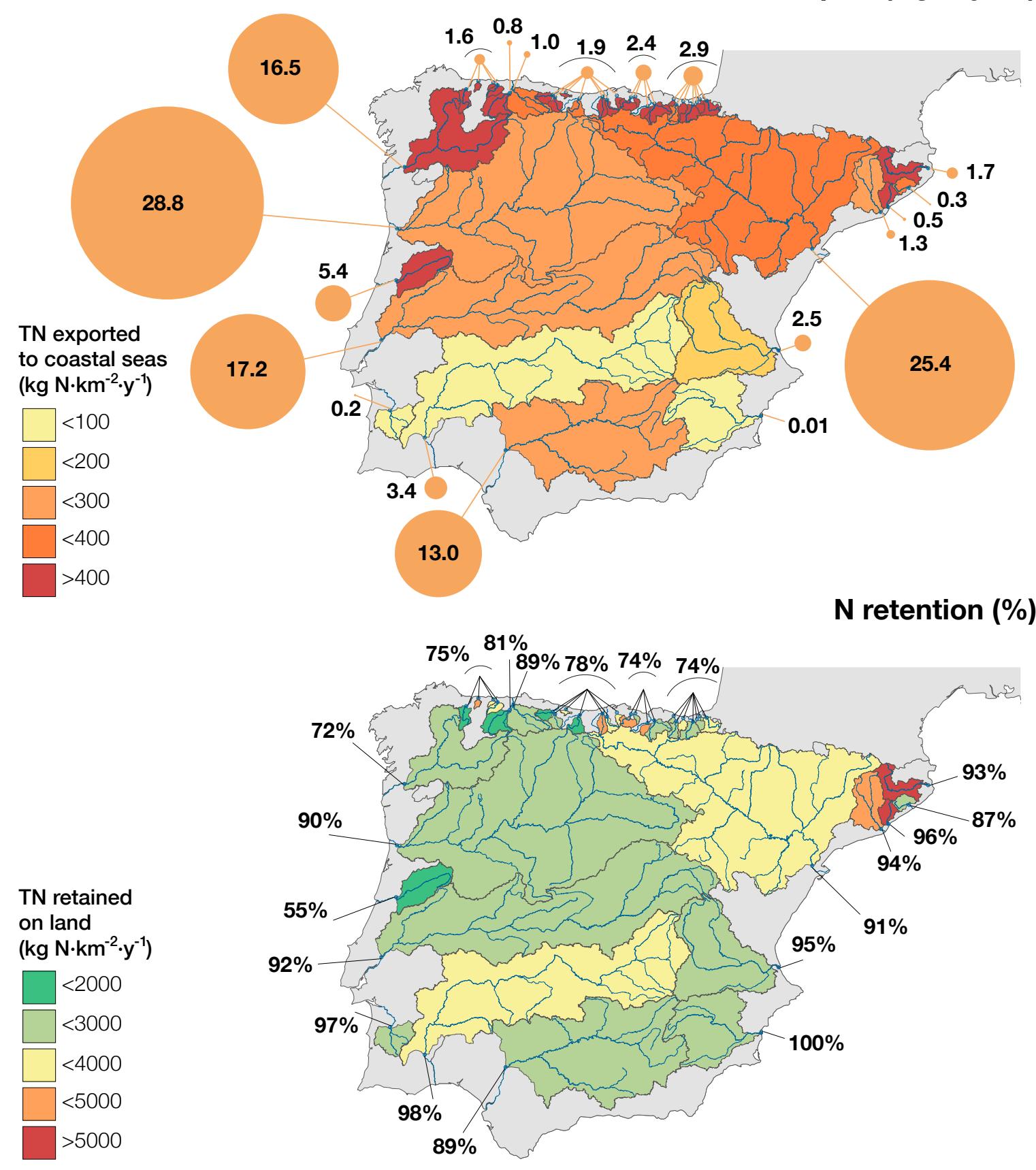

Fig. 4 


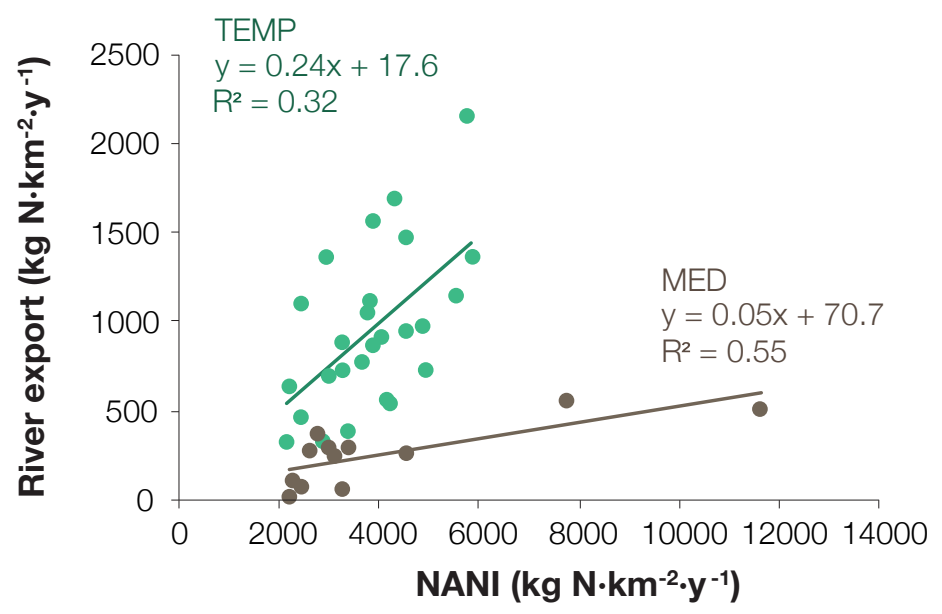

Fig. 5 

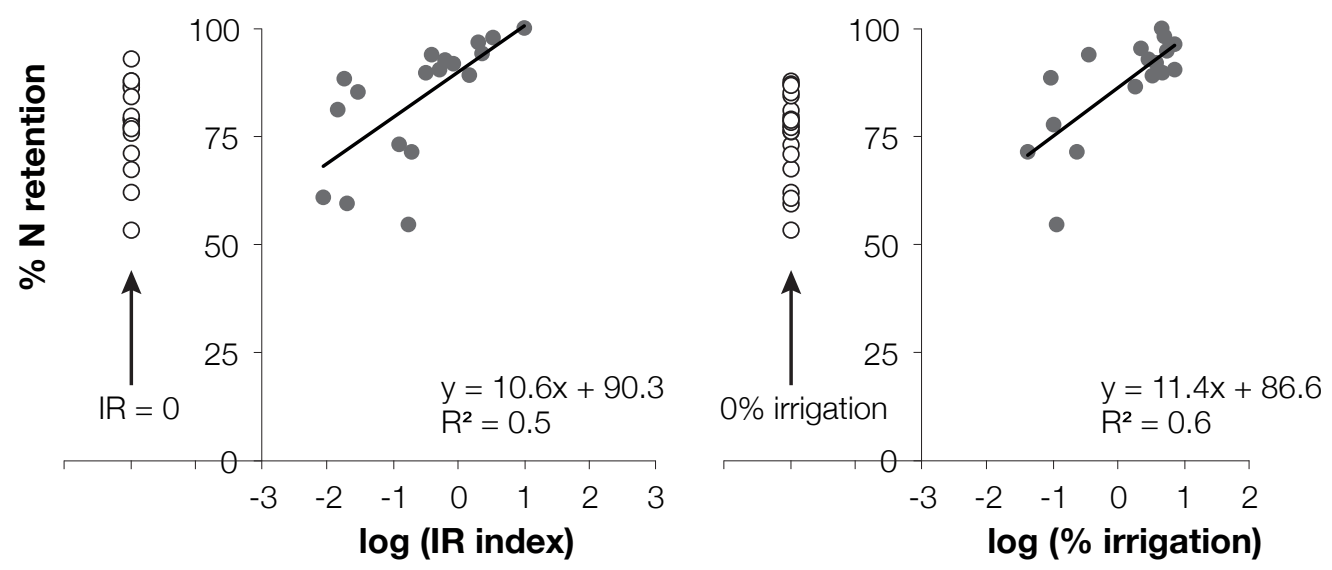

Fig. 6 